\title{
COVID-19 Pandemisinde Bilgi Edinme Kaynakları, Medya Kullanım Alıșkanlıkları ve Așıya Yönelik Tutumlar
}

\author{
Information Sources, Media Usage Habits and \\ Attitudes Towards Vaccination in the COVID-19 Pandemic
}

\author{
Çağlar GENÇ 1
}

\begin{abstract}
Öz
Günümüz teknoloji yoğun ortamda bilişim ve iletişim teknoloji ve uygulamalarında yaşanan yeniliklerle birlikte bireylerin bilgiye olan erişimi de büyük bir hızla artmıştır. Erişim olanaklarının artması ile birlikte bireyler artık ilgi alanlarına giren konularda pek çok farklı bilgi kaynağına kolayca ulaşabilmektedir. Bilgilerin hangi kaynaktan elde edildiği ve ne kadar güvenilir olduğu üzerinde önemle durulması gereken bir husustur. Çalışmanın amacı, COVID-19 pandemisi süreci ile ilgili bilgi edinmede referans gruplarına ve medyaya yönelik güveni, COVID-19 hastalığına yönelik algıyı ve COVID-19 aşısına yönelik tutumları ortaya çıkarmaktır. Çalışma çevrimiçi anket yöntemi ile gerçekleştirilmiştir. Olasılıklı olmayan örnekleme yöntemlerinden kartopu örnekleme ile 18 yaş üzeri 600 kişiye ulaşılmış, 592 anket araştırmaya dahil edilmiştir. Çalışma sonucunda elde edilen bulgulara göre aşı olma kararını en çok etkileyen grup doktorlardır. Geleneksel medyayı yüksek sıklıkta kullanan katılımcılar COVID-19'un nispeten daha az bulaştırıcı olduğunu düşünmekte ve COVID-19 aşısına yönelik daha olumlu tutum sergilemektedir. Sosyal medyayı yüksek sıklıkta kullanan katılımcılar, COVID-19 aşısı olma kararında sırasıyla aile üyeleri, arkadaş çevresi ve ünlü kişilerden etkilenmektedir. Sosyal medyaya yüksek düzeyde güven duyanlar COVID-19 aşısına yönelik daha olumlu tutuma sahip olmaktadır.
\end{abstract}

Anahtar Kelimeler: Medya kullanımı, Kaynak güvenirliği, Referans grupları, COVID-19 Algısı, COVID-19 AşıSı

\section{Abstract}

In today's technology-intensive environment, people's access to information has increased rapidly with the innovations in information and communication technologies and applications. With the increase in access opportunities, people can now easily access many different sources of information on topics that are of their interest. It is important to consider from which source the information is obtained and how reliable it is. The study aims to reveal trust in reference groups and the media in learning about the COVID-19 pandemic, perceptions about the COVID-19 disease and attitudes towards the COVID-19 vaccine. This study was carried out by using an online survey method. With snowball nonprobability sampling technique, 600 people over the age of 18 were reached, and 592 questionnaires were included in the study. According to the findings, the group that most influences the decision to be vaccinated is doctors. Participants who use traditional media with a high frequency think that COVID-19 is relatively less contagious and have a more positive attitude towards the COVID-19 vaccine. Participants who use social media with a high frequency are influenced by family members, friends, and famous people respectively in their decision to vaccinate against COVID-19. Those with a high level of trust in social media have a more positive attitude towards the COVID-19 vaccine.

Keywords: Media use, Resource reliability, Reference groups, Perception of COVID-19, COVID-19 Vaccine.

Araștırma Makalesi (Research Article) Gönderim Tarihi (Received): 30.08.2021

Kabul Tarihi (Accepted): 01.11.2021
Atıf (Cite as): Genç, C.. (2021). COVID-19 Pandemisinde Bilgi Edinme Kaynakları, Medya Kullanım Alıșkanlıkları ve Așıya Yönelik Tutumlar.

Akdeniz Üniversitesi Iletișim Fakültesi Dergisi, 36, s. 178-202, D0I:10.31123/akil. 988587.

1 Dr. Öğr. Üyesi, Anadolu Üniversitesi İletişim Bilimleri Fakültesi, cgenc@anadolu.edu.tr, 0000-0001-9397-8013 


\section{Giriș}

ünümüz teknoloji yoğun ortamda bilişim ve iletişim teknoloji ve uygulamalarında yaşanan 7 yeniliklerle birlikte insanların bilgiye olan erişimi de büyük bir hızla artmıştır. Erişim olanaklarının artması ile birlikte insanlar artık ilgi alanlarına giren konularda pek çok farklı bilgi kaynağına kolayca ulaşabilmektedir. Bilginin paylaşılması her ne kadar olumlu ve masum görünse de özellikle internet ortamında yayılan bilgilerin doğruluğu konusunda ciddi sıkıntılar gözlemlenmektedir. Bu bağlamda insan hayatının ayrılmaz bir parçası olan sağlık alanında yayılan bilgilerin doğruluğu oldukça önem taşımaktadır. Bilgilerin hangi kaynaktan elde edildiği ve bu kaynaklara yönelik güvenirlik üzerinde önemle durulması gereken bir husustur. Özellikle yeni medyada, farklı kimliklere bürünerek sağlığımızı yakından ilgilendiren konularda genellikle denetime tabi olmayan ve doğruluğu tartışmalı pek çok bilgi iletişim evreninde dağıtıma girmektedir. Hatta bu alan önemli bir rant alanı olarak neredeyse modern tıbba rakip olacak şekilde günlük hayatta çeşitli iletişim mecralarında karşımıza çıkmaktadır. Sağlığımızı hayati derecede ilgilendiren bu konulardan biri de güncel COVID-19 pandemisi ve buna yönelik aşı çalışmalarıdır. Bu çalışmada bireylerin bilgi kirliliğinin yoğun olduğu bir süreçte COVID-19 pandemisine yönelik başvurdukları bilgi edinme kaynakları, medyaya yönelik güven algıları ve aşılamaya yönelik tutumları incelenmiştir.

\section{COVID-19 Pandemisinde Dolașımda Olan Bilgilerin Güvenirliği}

Pandemi kavramının anlamını irdelediğimizde, "Birden fazla ülke veya kıtada, çok geniş bir alanda yayılarak etkisini gösteren salgın hastalıklar" şeklinde tanımlanmış olduğu görülmektedir. Konu ile ilgili Dünya Sağlık Örgütü (DSÖ), bir hastalığın pandemi olarak kabul edilebilmesi için üç kriter aramaktadır. Bunlardan ilki yeni bir virüs veya mutasyona uğramış bir etkenin varlığı, ikincisi bu etkenin kolayca insanlara geçmesi ve üçüncüsü de insandan insana devamlı ve rahatlıkla bulaşabilmesidir. Pandemi ilanı DSÖ tarafından belirlenen kriterler gerçekleştiği takdirde ilan edilmektedir. Yani ortaya çıkan yeni virüs ya da hastalık etkeninin insandan insana kolay bir şekilde hızlıca yayılıp tüm ülkeler için tehdit oluşturması sonucunda pandemi ilan edilir (COVID-19 Pandemi Değerlendirme Raporu, 2020, s.19).

COVID-19 pandemisi sürecinde gerçek olmayan çeşitli bilgiler üretilerek sosyal medya aracılığıyla erişime sunulmuştur. Bunun bir yansıması olarak da salgının yarattığı korku, panik ve belirsizlik artmış ve insanlar da sosyal ağlar ve dahil oldukları çevrimiçi gruplardan elde ettikleri bilgilerin güvenilirliğini sorgulamaya gerek duymadan paylaşmıştır. DSÖ sosyal mecralarda gerçekleşen bu bilgi kirliliğini infodemi olarak adlandırırken infodeminin de en az virüs kadar tehlikeli olduğu ve halk sağlığını tehdit ettiğini belirtmiştir (Aydın, 2020, s.77).

Daha önce kitap, dergi ve sağlık çalışanlarının bilgileri bünyesinde olan tıbbi bilgi kaynaklarına sanal ortam üzerinden ulaşabilme kolaylığı hasta-hekim dinamiklerini önemli ölçüde etkilemiştir. Bu durum, sağlık konusunda karar verme mekanizmasının giderek hasta-hekim arasında paylaşılmış kanaate dönüşmesine neden olmuştur. Bu bazı açılardan fayda sağlasa da internet ortamında bulunan bazı yanlış bilgilerin, özellikle bağışıklama kararı gibi kararlarda ebeveynlerin kafasının karışmasına neden olmaktadır (Kılıçaslan, 2020, s.33).

Sosyal medyanın yaygın kullanımındaki artış sonucu infodemi, COVID-19 ile mücadeleyi zorlaştıran en önemli etkenlerden biri haline getirmiştir. Pandemi ile birlikte insanlara doğru bilginin iletilmesinin 
gerekliliği anlaşılmıştır. Bu bağlamda söylenti ve yanlış bilgilerin belirlenmesi ve toplulukların değer yapıları da göz önünde bulundurularak bu yanlış bilgilerle aşamalı şekilde mücadele edilmesi önem kazanmıştır (Gölbaşı ve Metintaş, 2020, s.134).

Televizyon ve gazete gibi geleneksel mecraların aksine internet ortamında insanlar artık pasif alıcı konumundan çıkıp bilgiye anında erişmek isteyen aktif bilgi arayanlara dönüşmüştür. Sosyal medya kullanımında da bu dönüşüm sürecinde artış gerçekleşmiştir (Yılmaz ve Şahin, 2019, s.139).

Komplo teorileri, COVID-19 ile mücadelede büyüyen bir zorluk teşkil etmektedir. Virüsün ciddiyetine, pandemiyi hafifletme çabalarına duyulan ihtiyaç ve devlet ve halk sağlığı topluluklarının yönlendirmelerine meydan okuyan komplocu iddialar, internetin karanlık köşelerinden Facebook sayfalarına ve hatta seçilmiş yetkililere taşınmıştır. Komplo teorileri, kurumlara olan güveni aşındırarak ve gerçekler üzerinde kafa karışıklığı yaratarak kolektif eylemi ve iş birliğini engellemektedir. Bu komplo teorileri ve bunlardan sorumlu gruplar maske kullanımı, sokak kısıtlamaları gibi bulaş azaltma çabaları, halk sağlığına yönelik talimatları ve aşılanmaya yönelik çabaları da bozmaya çalışmaktadırlar (Hunt, 2020, s.2).

Facebook ve Google gibi bazı şirketler COVID-19 ile ilgili kendi platformlarındaki içeriklere yönelik özellikle dolandırıcılıkveyanlış bilgiaktarılmasınınönüne geçmekadına denetimgerçekleştireceklerini beyan eden bir ortak bildiri açıklamışlardır. Sosyal medyada ortaya çıkan bilgi kirliliğinin engellenmesi ve insanların sosyal medyayı doğru kullanabilmelerine yönelik olarak kamu sağlığından sorumlu kurumlar ve sosyal medya alanında faaliyet gösteren firmalar dijital okuryazarlığı teşvik etmelidir. Pandemi sonrası süreçte de konu ile ilgili araştırmalar devam ettirilerek sosyal medyada doğru bilgilerin insanlara ulaştırılması sağlanmalıdır (Kırık ve Özkoçak, 2020, s.151).

\section{Güvenirlik Ekseninde Bilgi Kaynağı Olarak Referans Grupları ve Medya}

Referans grubu, bir bireyin fikir, değer yargıları, tutum ve davranışlarını doğrudan veya dolaylı olarak etkileyen insan topluluğudur. Referans grubu, bireyin ailesi ve yakın çevresi ile üye olmadığı gruplar ve direkt ilişkili olmadığı kişilerden oluşur (aktaran Karaca, 2016, s. 213). Referans grupları, satın alma niyetinden oy verme davranışına kadar iletişim davranışımızla ilişkili pek çok alanda etkiye sahiptir denilebilir.

Bu çalışmada, COVID-19'a yönelik bilgi elde etmede ve COVID-19 aşısı olma konusunda, aile üyeleri, doktorlar, politikacılar ve mecralar gibi çeşitli referans gruplarının güvenilirlikleri incelenmiştir. O’Keefe (1990) güvenilirliği, iletişimcinin inanılırlığı ile ilgili alıcının yargıları olarak ifade eder (aktaran Suher, 2017, s. 298). Adler vd. (2014) ise, güven kavramını bilgiyi verenin güvenilirliği olarak tanımlamışlardır. Bilgiyi veren kişi iletişim sürecinde kaynak olarak konumlandırıldığından kaynak güvenirliği kuramının çalışma mekanizmasını ortaya koymak yararlıdır. İletişim süreci bakımından ele aldığımızda kaynak güvenilirliği kuramı, iletiyi gönderenin iletiyi alanlar üzerinde ne oranda ikna edici olduğu ve ne kadar güvenilir bulunduğunu açıklar. Kurama göre insanların karar verme davranışlarında kaynağın güvenilirliğine göre ikna olma derecesi değişir ve karar alma davranışı gerçekleşir. Dolayısıyla bireyler, karar alırken güvendikleri kaynakları dikkate alırlar (aktaran Özdemir vd., 2021, s. 117-118).

İnsanlar bilginin ana kaynağını kitle iletişim araçları olarak görmüşlerdir. Kitle iletişim araçlarının güvenirliği kamuya karşı dürüst olması olarak tanımlanır. Güvenirlik araştırmaları mecranın 
özelliklerine göre, gazetenin televizyona karşı güvenirliği gibi alt alanlara dağılır. TV'nin en güvenilir kaynak olarak görüldüğü birçok araştırma vardır (aktaran Suher, 2017, s. 320). Bu çalışmada, geleneksel mecraların sosyal medya mecralarına karşı güvenirliği ele alınmaktadır.

\section{COVID- 19 Așısı Karar Süreci ve Referans Grupları}

Pandemi ile baş edilebilmesi amacıyla pek çok ülkeden ilaç ve aşı çalışmaları ile ilgili duyuruların peşi sıra geldiği bir dönemde karşımıza bu sefer de aşıların güvenilirliği ile ilgili farklı bilgiler çıkmaktadır. Sade vatandaşların yanı sıra bilim insanlarının da dâhil olduğu şüphe iddiaların havada uçuştuğu bu süreçte zihinleri meşgul eden en önemli sorulardan bazıları aşıların yan etkisinin olup olmadığı, aşıların bağışıklık kazandırıp kazandırmadığı ve aşıyı üreten ülkenin ya da kuruluşun ne kadar güvenilir olduğudur. Bu süreçte yakın dönemde hızla artan aşı karşıtlığı da kendine uygun bir propaganda zemini bulmuştur.

Geçmişe oranla aşı karşıtı fikirler, özellikle internet ve sosyal medya aracılığıyla günümüzde çok daha hızlı bir şekilde yayılmaktadır. Aşılanma ile bağışıklamaya güvenmeyen marjinal bir kesim bugün olduğu gibi gelecekte de var olacaktır. Bu kesim kanıtlanmış bilimsel olgular yerine algılar üzerinden aşı karşıtı kampanyalar aracılığı ile aşıların nedeni bilinmeyen hastalıklara sebebiyet verdiği, aşılanmanın bağışıklık sisteminde olumsuz etkiler yarattığı, bu etkilerin saklandığı, aşı politikalarının ticari sebeplerle hazırlandığı gibi birtakım iddiaları yaymaktadırlar (Aker, 2018, s.177). Aşı karşıtları kabaca 3 grupta incelenebilir (Ataç ve Aker, 2014, s.44-45):

- Kâr/zarar ilişkisini yeterli görmeyenler

- Risk altında olduğunu düşünmeyenler

- Dini, felsefi ya da komploya dayalı sebeplerle karşı çıkanlar.

DSÖ aşılanmaya yönelik reddin gerekçelerinin bireysel, toplumsal, bağlamsal ve örgütsel olmak üzere beş ana başııta sırlamıştır. Yurtdışı çalışmalarında aşılarla ilgili suçlamalara yönelik tespitlerden bazıların şöyledir: Aşıların içeriklerinde zararlı kimyasallar ve toksik maddeler bulunmaktadır, aşı üreten firmalar bu işten büyük gelir elde etmektedir ve bu durumu art niyete çevirebilirler, hastalıklardan korunmada doğal yöntemler aşılardan daha etkilidir (Bozkurt, 2018, s.72).

Aşı kabulü ya da reddi ile ilgili birtakım süreçler vardır. Bunlardan biri olan aşı karar süreci dendiğinde karşımıza aşılanmayı kabul edenlerden reddedenlere uzanan bir süreç çıkmaktadır. Bir diğer süreç ise aşı kararsızlık sürecidir. Dünya Sağlık Örgütü'ne bağlı SAGE (Strategic Advisory Group Experts on Immunization) 2014 yılında hazırladığı raporda aşı kararsızlığını, gerekli hizmetin verilmesine rağmen aşıya yönelik kabulde gecikme ya da aşı olmayı reddetme şeklinde belirtmektedir. Aşıya yönelik kararsızlık, zaman, mekân ve aşıya bağlı olarak değişiklik göstermektedir. (Özata ve Kapusuz, 2019, s.68).

Aşı reddine yönelik olarak her ne kadar devletlerin yaklaşımları etkili görülse de dinsel ve felsefi açıdan kitlelerin görüşlerini yönlendirebilen birtakım bireyler ya da oluşumlar ile iletişim araçları ve özellikle sosyal medyanın etkisi de oldukça önemli yer tutmaktadır. Ülkelerin sadece kamu sağlığını korumaya yönelik yaklaşımları gerçekleştirmeleri yeterli değildir. Aynı zamanda toplumun bilgilendirilmesine, aşılara yönelik güven duygusunun pekiştirilmesine yönelik bilimsel çalışmalar gerçekleştirilmeli, sağlık bakanlıkları koordinasyonunda kanaat önderlerinin iletişim araçları vasıtası ile toplumun aydınlatılmasına destek olması gerekmektedir. Ayrıca aşı karşıtları tarafından 
medya üzerinden yayılan yanlış ve bilimsellikten uzak bilgilerin de mutlaka kontrol altına alınması gerekmektedir (Yüksel ve Topuzoğlu, 2019, s.255).

Türkay, Ay ve Aktekin (2017) tarafından gerçekleştirilen çalışmada kişilerin aşılara yönelik bilgi kaynakları incelendiğinde sırasıyla \%49,3 ile "televizyon" ilk sırada yer alırken "internet" \%44,2 ile ikinci, "doktor" \%41 ile üçüncü, "çevre-komşu-arkadaş" ise \%31,4 ile dördüncü sırada yer almıştır. Katılımcıların aşı uygulamalarına yönelik görüşleri incelendiğinde ise katılımcıların \%95,4'ü medyadaki aşı karşıtı haberler/politik söylemlerin aşı uygulamaları konusundaki düşüncelerini etkilemediğini, \%93,8'i kendimi aşı karşıtı olarak tanımlamadığını, \%79,3'ü ise "hastalık geçirerek bağışıklık kazanıımasının aşı yaptırmaktan daha etkili buluyorum, bu nedenle aşı yaptırmak istemem" yönündeki ifadeye katılmadıklarını belirtmişlerdir. Bolatkale vd. (2019) tarafından gerçekleştirilen çalışmada katılımcılar, erişkin aşıları hakkında bilgi kaynaklarını: "doktor" (\%49,3), "TV-gazeteradyo" (\%41,1), "internet "'(\%23,3) ve "yakınımdan-komşudan" $(\% 5,5)$ şeklinde belirtmişlerdir.

Uyar vd. (2019, s. 292) tarafından gerçekleştirilen 18 yaş üstü kişilerin aşılar hakkındaki bilgi, tutum ve davranışlarının belirlenmesine yönelik araştırmada katılımcıların \%65’i aşılamayla ilgili bilgileri sağlık çalışanlarından, \%24'ü ise internetten/televizyondan öğrendiklerini belirtmişlerdir. Okyay ve Abacıgil'in (2016) editörlüğünü yaptığı çalışmada, katılımcılar sağlık konusunda en güvenilir bulduğu bilgi kaynakları, sağlık çalışanı $(\% 69,5)$, radyo/televizyon $(\% 6,3)$, kitap/broşür $(\% 5,5)$, internet $(\% 5,3)$, aile üyeleri $(\% 4,6)$, yazılı basın (gazete, dergi vb.) $(\% 4,2)$ ve arkadaş $(\% 0,8)$ şeklinde belirtmişlerdir. Bertin vd. (2020, 7)'nin araştırması, COVID-19 ile ilgili çeşitli komplo teorilerinin katılımcıların aşı bilimine ve Covid-19 aşısı olma niyetine yönelik olumsuz bir tutum geliştirmelerine sebep olduğunu ortaya koymuştur.

\section{Amaç}

$\mathrm{Bu}$ araştırmanın amacı, COVID-19 pandemisine yönelik bilgi edinmede referans gruplarına ve medyaya yönelik güveni (geleneksel ve sosyal medya), COVID-19 hastalığına yönelik algıyı ve COVID-19 aşısına yönelik tutumları ortaya çıkarmaktır. Bununla birlikte COVID-19 pandemisi döneminde kullanıcıların medya kullanım sıklıkları ve medya platformlarına yönelik güvenleri (geleneksel ve sosyal medya) kümelendirilmeye çalışılmıştır. Bu sayede katılımcıların medya kullanım sıklık ile medya platformlarına güven düzeyleri belirlenmek istenmiştir. Öte yandan, medya kullanım sıklık ve medya platformlarına güven düzeyleri açısından COVID-19 pandemisiyle ilgili bilgi edinmede referans gruplarına güven, COVID-19 hastalığına yönelik algı ve COVID-19 aşısına yönelik tutumların nasıl değişim gösterdiği anlaşılmaya çalışılmıştır. Bu bağlamda aşağıdaki araştırma sorularına cevap aranmıştır:

1. Katılımcılar medya kullanım sıklıkları (geleneksel ve sosyal medya) açısından nasıl kümelenmektedir?

2. Katılımcılar medya platformlarına yönelik güven (geleneksel ve sosyal medya) açısından nasıl kümelenmektedir?

3. Medya kullanım sıklık düzeyi açısından referans gruplarına yönelik güven anlamlı bir biçimde farklılaşmakta midır?

4. Medya platformlarına yönelik güven düzeyi açısından COVID-19 aşısı olma kararında etkili olan gruplar anlamlı bir biçimde farklılaşmakta mıdır?

5. Medya kullanım sıklık düzeyi açısından COVID-19 aşısı olma kararında etkili olan gruplar anlamlı bir biçimde farklılaşmakta mıdır?

6. Medya platformlarına yönelik güven düzeyi açısından COVID-19 aşısı olma kararında etkili olan referans 
grupları anlamlı bir biçimde farklılaşmakta mıdır?

7. Medya kullanım sıklık düzeyi açısından COVID-19 hastalığına yönelik algı anlamlı bir biçimde farklılaşmakta mıdır?

8. Medya kullanım sıklık düzeyi açısından COVID-19 aşısına yönelik tutum anlamlı bir biçimde farklılaşmakta mıdır?

9. Medya platformlarına yönelik güven düzeyi açısından COVID-19 hastalığına yönelik algı anlamlı bir biçimde farklılaşmakta mıdır?

10. Medya platformlarına yönelik güven düzeyi açısından COVID-19 aşısına yönelik tutum anlamlı bir biçimde farklılaşmakta mıdır?

\section{Yöntem}

Nicel araşı̧ırma yöntemi ile gerçekleştirilen çalışmada kesitsel tarama modeli kullanılmıştır. Kesitsel tarama modeli aracılığı ile bir evren ya da evreni temsil eden örneklemin eğilimleri, tutumları ve algıları nicel olarak ve direkt tespit edilebilmektedir (Creswell, 2014, s. 13). Çalışmada kullanılan veriler, anket tekniğiyle elde edilmiştir ve ilgili anket, Anadolu Üniversitesi Sosyal ve Beşerî Bilimler Bilimsel Araştırma ve Yayın Etiği Kurulu'ndan 29.01.2021 tarihli 4/36 sayılı Etik Kurul Onay Kararı alındıktan sonra çevrimiçi bir biçimde dolaşıma konulmuştur. Çalışmada olasılıklı olmayan örnekleme yöntemlerinden kartopu örnekleme yöntemiyle Ocak 2021-Mart 2021 tarihlerinde arasında 18 yaş ve üzeri 600 kişiye ulaşılmıştır. Bireylerin kendi rızası ile muayene ve aşı olabilmesi için kanunen reşit olması gerekmektedir. Aksi takdirde veli onayı gerekmektedir. Bu yüzden katılımcılarda 18 yaş ve üzeri olma şartı aranmıştır.

Anket, demografik bilgiler; medya kullanım alışkanlıkları, sıklıkları ve medya platformlarına yönelik güven; COVID-19 bilgi kaynaklarına yönelik güven; COVID-19'a yönelik algılar ve COVID-19 aşısına yönelik tutumlar olmak üzere 5 bölümden oluşmaktadır. Ankette, katılımcıların medya kullanım sıklıkları ile medya platformlarına yönelik güvenleri 5'li Likert tipi biçiminde ölçümlenmiştir. Söz konusu platformlar kapsamında geleneksel medya; TV, gazete, dergi ve radyo olmak üzere dört platformla, sosyal medya; Facebook, Twitter, Instagram, YouTube, WhatsApp grupları, forum, blog ve sözlük, internet haber ve sağlık siteleri olmak üzere ele alınmıştır. Diğer taraftan ankette, Geniş vd. (2020)'nın COVID-19 hastalığına yönelik algı ile COVID-19 aşısına yönelik tutum ölçekleri derlenerek kullanılmıştır. COVID-19 hastalığına yönelik algı ölçeği yedi madde içermekte ve beşli Likert tipi biçimindedir (1 = Hiç Katılmıyorum; 5 = Tamamen Katılıyorum). COVID-19 aşısına yönelik tutum ölçeği dokuz maddeden oluşmakta ve beşli Likert tipi şeklindedir $(1=$ Hiç Katılmıyorum; 5 = Tamamen Katııyorum). Öte yandan, katılımcıların medya kullanım alışkanlıklarını ölçümleyebilmek için Yılmaz ve Şahin'in (2019) çalışmasında kullandığı ölçek derlenerek kullanıımıştır. Söz konusu ölçek beş maddeden oluşmakta ve beşli Likert şeklindedir ( 1 = Hiçbir Zaman; 5 = Her Zaman). Çalışmada kullanılan bütün ölçeklerin bu çalışmada kullanılabilmesi için ilgili yazarlardan izin alınmıştır.

Verilerin analizi sürecinde SPSS 25 programı kullanılmıştır. Çalışmada yer alan ölçeklere ilişkin güvenirlik ile geçerlik analizleri, açımlayıcı faktör analizi (AFA) ile Cronbach's Alpha katsayısının incelenmesi sonucunda kontrol edilmiştir. Bununla birlikte, araştırma sorularının cevaplanmasına yönelik frekans analizi, Ward ile k-ortalamalar kümeleme analizi ve bağımsız örneklemler t-test istatistikleri kullanılııştır. 


\section{Bulgular}

Çalışmada veri elde edilen kişi sayısı 600'dür. Elde edilen veriye yönelik ön kontrolde altı yanıtın birbirini tekrar edecek biçimde uygunsuz olarak doldurulduğunun tespit edilmesi üzerine veri setinden çıkartılmıştır. Ardından tek değişkenli normallik sayıltısı, Pallant (2011) SPSS veri analizi kılavuzuna göre incelenmiştir. Yapılan incelemeler neticesinde 9 gözlemin etkili veriye sahip olduğu görülmüş ve söz konusu gözlemlerin aritmetik ortalamaları ve \%5 kırpılmış ortalamaları birbirleriyle kıyaslanmıştır. Kıyaslama sonucunda iki ortalama arasında tespit edilen farkların düşük olduğu belirlendiği için (0,07 ile 0,09 arasında) çalışmada tek değişkenli normalliğin bir sorun oluşturmadığı belirlenmiştir. Diğer taraftan, Arifin (2015) tarafından ileri sürülen yöntem kullanılarak çalışmada kullanılan ölçeklerin maddelerine ilişkin Mahalanobis uzaklığı hesaplanmıştır. İlgili uzaklığı 0,001 anlamlılık düzeyinde aştığı görülen 2 gözlem, veri setinden silinmiştir. Bu bağlamda kalan 592 gözlemle, çalışmada gerek tek değişkenli gerekse çok değişkenli normalliğin sağlandığı sonucuna ulaşılmıştır.

\subsection{Katılımcılara ilișkin demografik bulgular}

Çalışmada yer alan katılımcıların (Tablo 1) \%45,3'ü kadın ve \%54,7'si erkektir. Katılımcıların yaş dağılımlarına bakıldığında çoğunluğu 21-30 yaş $(\% 37,5)$ arasındaki bireyler, en düşük grubu ise 20 yaş (18-20 yaş arası) ve altındaki $(\% 5,6)$ bireyler oluşturmaktadır. Eğitim durumuna bakıldığında katılımcıların \%72,3'ü üniversite mezunudur ve \%59'u çalışmaktadır. Çalışanların gelir düzeyleri ise, \%34,5 ile aylık kazanc 3000 TL - 5999 TL arasındadır.

Tablo 1. Katılımcıların Demografik Özellikleri

\begin{tabular}{|c|c|c|c|}
\hline Değişken & Seçenekler & $\mathrm{N}$ & $\%$ \\
\hline \multirow{2}{*}{ Cinsiyet } & Kadın & 268 & 45,3 \\
\hline & Erkek & 324 & 54,7 \\
\hline \multirow{5}{*}{ Yaş } & 20 yaş ve altında & 33 & 5,6 \\
\hline & $21-30$ yaş arası & 222 & 37,5 \\
\hline & 31-40 yaş arası & 158 & 26,7 \\
\hline & 41-50 yaş arası & 100 & 16,9 \\
\hline & 51 yaş ve üstünde & 79 & 13,3 \\
\hline \multirow{3}{*}{ Eğitim Durumu } & Lise ve altı & 68 & 11,5 \\
\hline & $\begin{array}{l}\text { Üniversite } \\
\text { (Önlisans ve } \\
\text { Lisans) } \\
\end{array}$ & 428 & 72,3 \\
\hline & Lisansüstü & 96 & 16,2 \\
\hline \multirow{4}{*}{ Aylık Gelir } & Aylık gelirim yok & 89 & 15,0 \\
\hline & 2999 TL ve altında & 119 & 20,1 \\
\hline & \begin{tabular}{|l}
$3000 \mathrm{TL}-5999 \mathrm{TL}$ \\
arası
\end{tabular} & 204 & 34,5 \\
\hline & \begin{tabular}{|l|}
$6000 \mathrm{TL}$ ve \\
üstünde \\
\end{tabular} & 180 & 30,4 \\
\hline \multirow{3}{*}{ Çalışma Durumu } & Çalışıyor & 349 & 59,0 \\
\hline & Çalışmıyor & 243 & 41,0 \\
\hline & Toplam & 592 & 100,0 \\
\hline
\end{tabular}




\subsection{Medya kullanım alıșkanlıklarına ilișkin bulgular}

Pandemi döneminde sıklıkla kullanılan mecralar incelendiğinde (Tablo 2) geleneksel medya bağlamında katılımcıların en sık kullandıkları mecra TV $(2,70)$ iken sosyal medya bağlamında Instagram $(2,56)$ olduğu görülür.

Tablo 2. Katılımcıların Medya Kullanım Sıklıkları $(n=592)$

\begin{tabular}{|l|l|c|c|}
\hline & Mecralar & Ortalama* $^{*}$ & Standart Sapma \\
\hline \multirow{4}{*}{ Geleneksel medya } & TV & 2,70 & 1,19 \\
\cline { 2 - 4 } & Gazete & 1,74 & 0,77 \\
\cline { 2 - 4 } & Radyo & 1,66 & 0,67 \\
\cline { 2 - 4 } & Dergi & 1,58 & 0,74 \\
\hline \multirow{5}{*}{ Sosyal medya } & Facebook & 1,80 & 0,86 \\
\cline { 2 - 4 } & Twitter & 1,95 & 0,88 \\
\cline { 2 - 4 } & Instagram & 2,56 & 0,91 \\
\cline { 2 - 4 } & YouTube & 2,40 & 0,96 \\
\cline { 2 - 4 } & Pinterest & 1,34 & 0,62 \\
\cline { 2 - 4 } & Snapchat & 1,16 & 0,43 \\
\cline { 2 - 4 } & Bloglar & 1,42 & 0,69 \\
\cline { 2 - 4 } & Forumlar & 1,48 & 0,70 \\
\hline
\end{tabular}

*1 = Hiçbir Zaman; 5 = Her Zaman

Medya kullanım alışkanlıkları bağlamında katılımcıların medya kullanım amaçlarına yönelik ortalamalar Tablo 3'te verilmiştir. En yüksek ortalama $(4,20)$ gündemi takip etmek, gelişmelerden haberdar olmak iken, en düşük ortalama $(2,60)$ içerik (yorum, görsel, video) paylaşmaktır.

Tablo 3. Katılımcıların Medya Kullanım Amaçları $(n=592)$

\begin{tabular}{|l|c|c|}
\hline Medya Kullanım Amaçları & Ortalama $^{*}$ & Standart Sapma $^{-}$ \\
\hline Gündemi takip etmek, gelişmelerden haberdar olmak & 4,20 & 0,95 \\
\hline Araştırmak, bilgi edinmek & 4,00 & 0,91 \\
\hline Eğlenmek & 3,36 & 1,20 \\
\hline İletişim başlatma ya da sürdürme & 3,07 & 1,30 \\
\hline İş birliği yapma & 2,85 & 1,30 \\
\hline İçerik (yorum, görsel, video) paylaşmak & 2,60 & 1,27 \\
\hline
\end{tabular}

*1 = Hiçbir Zaman; 5 = Her Zaman

\subsection{Mecralara duyulan güven ile ilișkili bulgular}

Katılımcıların COVID-19 konusunda bilgi elde etmek için başvurdukları mecralar ve bu mecralara duydukları güven incelendiğinde; bilgi kaynağı olarak geleneksel medyayı tercih edenlerin TV $(2,72)$ 'yi daha güvenilir bulduğu, sosyal medyayı tercih edenlerin ise İnternet haber ve sağlık sitelerini $(3,29)$ daha güvenilir bulduğuna dair veriler Tablo 4'te verilmektedir. 
Tablo 4. Mecraya Duyulan Güven ( $n=592)$

\begin{tabular}{|l|l|c|c|}
\hline & Mecra & Ortalama* & Standart Sapma \\
\hline \multirow{5}{*}{ Geleneksel medya } & TV & 2,72 & 1,05 \\
\cline { 2 - 4 } & Gazete & 2,62 & 1,06 \\
\cline { 2 - 4 } & Dergi & 2,65 & 1,08 \\
\cline { 2 - 4 } & Radyo & 2,55 & 1,08 \\
\hline \multirow{5}{*}{ Sosyal medya } & Facebook & 1,90 & 0,99 \\
\cline { 2 - 4 } & Twitter & 2,75 & 1,21 \\
\cline { 2 - 4 } & Instagram & 2,21 & 1,09 \\
\cline { 2 - 4 } & YouTube & 2,51 & 1,13 \\
\cline { 2 - 4 } & WhatsApp grupları & 2,15 & 1,13 \\
\cline { 2 - 4 } & Forum, Blog ve Sözlük & 2,38 & 1,14 \\
\cline { 2 - 4 } & Internet haber ve sağlık siteleri & 3,29 & 1,05 \\
\hline
\end{tabular}

*1 = Hiç Güvenilmez; 5 = Çok Güvenilir.

Tablo 5'te katılımcıların COVID-19 ile ilgili konularda bilgi almak için hangi referans grubunun ne derecede güvenilir bulunduğuna yönelik bulgular yer almaktadır. Buna göre en güvenilir bulunan kaynak doktorlardır $(4,46)$. Doktorları, doktorlar dışındaki sağlık personeli $(3,97)$ takip ederken en düşük güven sosyal medya fenomenlerine (1.67) duyulmaktadır.

Tablo 5. Referans Grubuna Duyulan Güven İle İlişkili Bulgular ( $n=592)$

\begin{tabular}{|l|c|c|}
\hline Referans Grubu & Ortalama $^{*}$ & Standart Sapma \\
\hline Doktorlar & 4,46 & 0,69 \\
\hline Doktorlar dışındaki sağlık personeli & 3,97 & 0,90 \\
\hline Aile üyeleri & 3,38 & 1,21 \\
\hline Arkadaş çevresi & 3,11 & 1,09 \\
\hline Medya mensupları & 2,33 & 1,07 \\
\hline Ünlü kişiler & 2,03 & 0,98 \\
\hline Siyasetçiler & 1,86 & 1,00 \\
\hline Din adamları & 1,69 & 1,03 \\
\hline Sosyal medya fenomenleri & 1,67 & 0,89 \\
\hline
\end{tabular}

*1 = Hiç Güvenilmez; 5 = Çok Güvenilir.

\subsection{Așı olma kararına etki eden referans gruplarına ilișkin bulgular}

Çalışmada, aşı olma kararına etki eden kişi/gruplar incelendiğinde (Tablo 6) katılımcıların aşı olma kararlarını en çok etkileyen grubun doktorlar $(4,26)$ en az etkileyen grubun ise sosyal medya fenomenleri $(1,47)$ olduğu görülmektedir.

Tablo 6. Katılımcıların Aşı Olma Kararında Etkili Olan Referans Grupları $(n=592)$

\begin{tabular}{|l|c|c|}
\hline Referans Grubu & Ortalama* $^{*}$ & $\begin{array}{c}\text { Standart } \\
\text { Sapma }\end{array}$ \\
\hline Doktorlar & 4,26 & 1,03 \\
\hline Doktorlar dışındaki sağlık personeli & 3,60 & 1,29 \\
\hline Aile üyeleri & 2,98 & 1,42 \\
\hline Arkadaş çevresi & 2,49 & 1,28 \\
\hline Medya mensupları & 1,73 & 1,02 \\
\hline
\end{tabular}




\begin{tabular}{|l|c|c|}
\hline Siyasetçiler & 1,61 & 1,00 \\
\hline Ünlü kişiler & 1,56 & 0,93 \\
\hline Din adamları & 1,47 & 0,93 \\
\hline Sosyal medya fenomenleri & 1,39 & 0,79 \\
\hline
\end{tabular}

*1 = Hiç Etkilemez; 5 = Tamamen Etkiler.

\section{5. Ölçeklere ilișkin bulgular}

Çalışmada kullanılan a) COVID-19 algısı ve b) COVID-19 aşısına yönelik tutum ölçeklerinin faktörlere göre dağılımını ortaya çıkarabilmek için açımlayıcı faktör analizinden (AFA) faydalanılmıştır. COVID-19 algısı ölçeği için KMO değeri 0,790 ve Barlett Küresellik Testi anlamlı çıkmıştır $\left(x^{2}\right.$ : 1430,8; df: 21; $p<0,001)$. COVID-19 aşısına yönelik tutum ölçeği için KMO değeri 0,894 ve Barlett Küresellik Testi anlamlıdır ( $x^{2}: 3245,1$; df: 36; $p<0,001$ ). Açıklanan varyanslar a'nın (COVID-19 algısı) bulaştırıcılık faktörü için 46,20 ve tehlikelilik faktörü için 17,20'dir. Açıklanan toplam varyans ise 63,4'tür. Öte yandan, b'nin (COVID-19 aşısına yönelik tutum) olumlu tutum faktörü için açıklanan varyans 54,28 ve olumsuz tutum faktörü için 13,61'dir. Açıklanan toplam varyans ise 67,89'dur (Hair vd., 2014, s. 102). Bu sonuçlar AFA'nın yorumlanması adına yeterlidir. Çalışmada yer alan ölçeklerin faktör yükleri 0,501 $-0,895$ arasında dağılmaktadır. Bununla birlikte, güvenirlik analizi sonucunda Cronbach's a katsayısının A için tehlikelilik faktörü 0,72 ve bulaştırıcılık faktörü 0,80 olarak tespit edilmiştir. B'nin olumlu tutum faktörü için a katsayısı 0,93 ve olumsuz tutum için 0,77 olduğu belirlenmiştir. Dolayısıyla ölçekler güvenir kabul edilebilir (Kalaycı, 2017, s. 405). COVID-19 algısı ölçeğinde en yüksek aritmetik ortalamaya bulaştırıcılık faktörünün sahip olduğu görülürken ( $=4,05 ; S S=0,74$ ) aşıya yönelik tutum ölçeğinde en yüksek aritmetik ortalamaya olumlu tutumun sahip olduğu belirlenmiştir ( $=3,20$; SS $=1,12$ ). Bu sonuçlar katılımcıların COVID-19'un bulaştırıcı olduğu algısına sahip olduklarını gösterirken COVID-19 aşısına yönelik de olumlu bir tutuma sahip olduklarının altını çizmektedir.

Tablo 7. AFA ve Güvenirlik Analizi Sonuçları ile Betimsel İstatistikler

\begin{tabular}{|c|c|c|c|c|c|c|}
\hline Madde & $\bar{x}$ & SS & FY & AV & ÖD & $\mathrm{CA}$ \\
\hline COVID-19 Algısı = Bulaştırıcılık & 4.05 & 0,74 & & \multirow{4}{*}{17,20} & \multirow{4}{*}{1,20} & \multirow{4}{*}{0,80} \\
\hline Bu hastalık herkese bulaşabilir. & 4,52 & 0,85 & 0,870 & & & \\
\hline Kolayca bulaşan bir hastalıktır. & 4,30 & 0,96 & 0,833 & & & \\
\hline $\begin{array}{l}\text { Hastalığın kadınlara ve erkeklere bulaşma olasılığı } \\
\text { benzerdir }\end{array}$ & 4,14 & 1,02 & 0,764 & & & \\
\hline COVID-19 AlgıSI = Tehlikelilik & 1,99 & 0,96 & & \multirow{4}{*}{46,20} & \multirow{4}{*}{3,23} & \multirow{4}{*}{0,72} \\
\hline Bu hastalık söylendiği kadar tehlikeli değil. & 2,06 & 1,28 & 0,869 & & & \\
\hline Medya salgını abartıyor. & 2,11 & 1,30 & 0,836 & & & \\
\hline Virüs ölümcül bir hastalığa neden olmaktadır*. & 4,18 & 1,02 & 0,636 & & & \\
\hline Aşıya Yönelik Tutum = Olumlu Tutum & 3,20 & 1,12 & & \multirow{5}{*}{54,28} & \multirow{5}{*}{4,88} & \multirow{5}{*}{0,93} \\
\hline $\begin{array}{l}\text { Ailemdekilerin bu hastalıkla ilgili geliştirilen aşıyı } \\
\text { olmasını isterim. }\end{array}$ & 3,41 & 1,23 & 0,895 & & & \\
\hline $\begin{array}{l}\text { İlk fırsatta bu hastalıkla ilgili geliştirilen aşıyı olmak } \\
\text { isterim. }\end{array}$ & 3,13 & 1,31 & 0,894 & & & \\
\hline $\begin{array}{l}\text { Bence herkes bu hastalıkla ilgili geliştirilen aşıyı } \\
\text { yaptırmalı. }\end{array}$ & 3,35 & 1,22 & 0,882 & & & \\
\hline $\begin{array}{l}\text { Geliştirilen aşı hakkında yapılan açıklamalara } \\
\text { güveniyorum. }\end{array}$ & 2,94 & 1,17 & 0,820 & & & \\
\hline
\end{tabular}




\begin{tabular}{|c|c|c|c|c|c|c|}
\hline Aşıya Yönelik Tutum = Olumsuz Tutum & 2,62 & 0,81 & & \multirow{6}{*}{13,61} & \multirow{6}{*}{1,22} & \multirow{6}{*}{0,77} \\
\hline Geliştirilen aşı hastalığın bulaşmasına neden olabilir. & 2,34 & 1,05 & 0,781 & & & \\
\hline $\begin{array}{l}\text { Geliştirilen aşının koruyucu etkisinin olmadığını } \\
\text { düşünüyorum. }\end{array}$ & 2,38 & 1,05 & 0,752 & & & \\
\hline Geliştirilen aşı tehlikelidir. & 2,29 & 1,00 & 0,752 & & & \\
\hline $\begin{array}{l}\text { Geliştirilen aşının etkililiğinin yeterince test } \\
\text { edilmediğini düşünüyorum. }\end{array}$ & 3,26 & 1,25 & 0,621 & & & \\
\hline $\begin{array}{l}\text { Aşı olmadan da salgını atlatabileceğimi } \\
\text { düşünüyorum. }\end{array}$ & 2,84 & 1,26 & 0,501 & & & \\
\hline
\end{tabular}

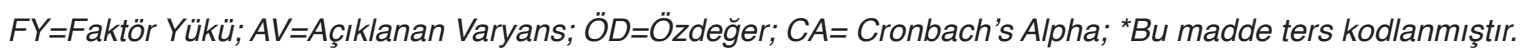

\subsection{Kümeleme analizine ilișkin bulgular}

Katıımcıları, medya kullanım sıklıklarına ve medyaya duyulan güvene göre gruplandırabilmek amacıyla iki aşamalı kümeleme analizi uygulanmıştır. İlk aşamada kümeleme analizinden önce Ward yöntemi aracılığıyla araştırmaya katılanların kullanım sıklığı ve güvenleri incelenmiştir. Sınıflandırma yapabilmek amacıyla mecra kullanım sıklıkları ve güven frekansları kullanılmıştır (Hair vd., 2014, s. 442). Elde edilen sonuçlara dayanarak katıımcılar medya kullanım sıklıkları ve medyaya duyulan güven açısından iki kümeye ayrılmıştır. İkinci olarak k-ortalamalar yöntemi kullanılarak ilk aşamada elde edilen iki kümeli sınıflandırmanın güvenirliği test edilmiştir. Ward ve k-ortalamalar yöntemi sonucu ulaşılan ortalamalar birbirlerine yakındır. Bu sebeple medya kullanım sıklığı açısından geleneksel medyayı a) düşük sıklıkta kullananlar ve b) yüksek sıklıkta kullananlar; sosyal medyayı a) düşük sıklıkta kullananlar ve b) yüksek sıklıkta kullananlar; duyulan güven açısından geleneksel medyaya yönelik a) düşük düzeyde güvene sahip olanlar ve b) yüksek düzeyde güvene sahip olanlar; sosyal medyaya yönelik a) düşük düzeyde güvene sahip olanlar ve b) yüksek düzeyde güvene sahip olanlar olarak bir sınıflandırma işlemi gerçekleştirilmiştir. Elde edilen kümelere ilişkin betimsel bilgiler aşağıdaki tablolarda gösterilmiştir.

Tablo 8. Katılımcıların Medya Kullanım Sıklığı Kümeleri

\begin{tabular}{|c|c|c|c|c|c|}
\hline & & \multicolumn{4}{|c|}{ Kümeler } \\
\hline & & \multicolumn{2}{|c|}{$\begin{array}{c}\text { Düşük } \\
(\mathrm{n}=265 ; \% 44,8)\end{array}$} & \multicolumn{2}{|c|}{$\begin{array}{c}\text { Yüksek } \\
(n=327 ; \% 55,2)\end{array}$} \\
\hline & & & SS & & SS \\
\hline \multirow{5}{*}{ Geleneksel medya } & TV & 1,57 & 0,49 & 3,62 & 0,71 \\
\hline & Gazete & 1,62 & 0,68 & 1,84 & 0,82 \\
\hline & Radyo & 1,60 & 0,58 & 1,71 & 0,64 \\
\hline & Dergi & 1,59 & 0,75 & 1,58 & 0,73 \\
\hline & Aritmetik Ortalama & 2,18 & 0,52 & 1,59 & 0,46 \\
\hline
\end{tabular}




\begin{tabular}{|l|l|c|c|c|c|}
\hline \multirow{5}{*}{} & & \multicolumn{2}{|c|}{$\begin{array}{c}\text { Düşük } \\
(\mathrm{n}=412 ; \% 69,6)\end{array}$} & \multicolumn{2}{c|}{$\begin{array}{c}\text { Yüksek } \\
(\mathrm{n}=180 ; \% 30,4)\end{array}$} \\
\cline { 2 - 6 } & Facebook & 1,85 & 0,89 & 1,69 & 0,79 \\
\hline & Twitter & 1,64 & 0,70 & 2,66 & 0,83 \\
\cline { 2 - 6 } & Instagram & 2,29 & 0,80 & 3,19 & 0,85 \\
\cline { 2 - 6 } & YouTube & 2,22 & 0,88 & 2,87 & 0,98 \\
\cline { 2 - 6 } & Pinterest & 1,20 & 0,51 & 1,66 & 0,72 \\
\cline { 2 - 6 } & Snapchat & 1,05 & 0,25 & 1,40 & 0,62 \\
\cline { 2 - 6 } & Bloglar & 1,14 & 0,38 & 2,07 & 0,81 \\
\cline { 2 - 6 } & Forumlar & 1,24 & 0,48 & 2,04 & 0,80 \\
\cline { 2 - 6 } & Aritmetik Ortalama & 1,55 & 0,25 & 2,16 & 0,40 \\
\hline
\end{tabular}

Tablo 8 geleneksel ve sosyal medya mecralarının düşük ve yüksek sıklıkla kullanılma durumlarını yansıtmaktadır. Buna göre, geleneksel medyayı yüksek sıklıkta kullanan katılımcıların ilk sıradaki tercihi TV $(3,62)$ olmuştur. Bununla beraber, sosyal medyayı yüksek sıklıkta kullanan katılımcıların ilk sıradaki tercihi instagram $(3,19)$ olmaktadır.

Tablo 9. Medyaya Yönelik Güven Kümeleri

\begin{tabular}{|c|c|c|c|c|c|}
\hline & & \multicolumn{4}{|c|}{ Kümeler } \\
\hline & & \multicolumn{2}{|c|}{$\begin{array}{c}\text { Düşük } \\
(\mathrm{n}=449 ; \% 75,8)\end{array}$} & \multicolumn{2}{|c|}{$\begin{array}{c}\text { Yüksek } \\
(n=143 ; \% 24,2)\end{array}$} \\
\hline & & & SS & & SS \\
\hline \multirow{5}{*}{ Geleneksel medya } & TV & 2,37 & 0,90 & 3,80 & 0,68 \\
\hline & Gazete & 2,24 & 0,87 & 3,80 & 0,62 \\
\hline & Radyo & 2,37 & 098 & 3,54 & 0,85 \\
\hline & Dergi & 2,15 & 0,87 & 3,80 & 0,62 \\
\hline & Aritmetik Ortalama & 2,28 & 0,69 & 3,73 & 0,43 \\
\hline \multirow{9}{*}{ Sosyal medya } & & \multicolumn{2}{|c|}{$\begin{array}{c}\text { Düşük } \\
(\mathrm{n}=287 ; \% 48,5)\end{array}$} & \multicolumn{2}{|c|}{$\begin{array}{c}\text { Yüksek } \\
(\mathrm{n}=305 ; \% 51,5)\end{array}$} \\
\hline & Facebook & 1,76 & 0,92 & 2,32 & 1,10 \\
\hline & Twitter & 2,64 & 1,20 & 3,08 & 1,19 \\
\hline & Instagram & 2,09 & 1,05 & 2,59 & 1,12 \\
\hline & YouTube & 2,35 & 1,11 & 3,04 & 1,03 \\
\hline & WhatsApp grupları & 2,06 & 1,10 & 2,45 & 1,20 \\
\hline & Forum, Blog, Sözlük vb. & 2,24 & 1,11 & 2,82 & 1,12 \\
\hline & $\begin{array}{l}\text { Internet haber ve sağlık } \\
\text { siteleri }\end{array}$ & 3,10 & 1,05 & 3,87 & 0,83 \\
\hline & Aritmetik Ortalama & 1,81 & 0,40 & 3,05 & 0,42 \\
\hline
\end{tabular}

Tablo 9'da görüldüğü üzere geleneksel medyanın yüksek düzeyde güvenilir bir kaynak olduğunu düşünenlerin en güvenilir bulduğu mecralar (3,80 ile) TV, gazete ve dergidir. Bir bilgi kaynağı olarak sosyal medyanın güvenirliğine bakıldığında, yüksek düzeyde güven kümesindeki katılımcıların en güvenilir bulduğu mecralar İnternet haber ve sağlık siteleri $(3,87)$ ile Twitter $(3,08)$ olarak bulgulanmıştır. 


\subsection{Medya kullanım sıklığı açısından referans gruplarının güvenirliğinin incelenmesi}

Geleneksel medyayı kullanma sıklığı kümeleri açısından COVID-19 bilgi kaynaklarına (referans gruplarına) yönelik güvenin anlamlı biçimde farklılaşıp farklılaşmadığını tespit edebilmek için bağımsız örneklemler t-test uygulanmıştır. Ulaşılan sonuçlar Tablo 10'da yer almaktadır.

Tablo 10. Geleneksel Medya Kullanım Sıklığı Kümeleri Açısından Referans Gruplarının Güvenirliği

\begin{tabular}{|c|c|c|c|c|c|c|c|}
\hline Referans Grupları & Küme & $\mathrm{n}$ & & SS & $\mathrm{t}$ & $\mathrm{df}$ & $p$ \\
\hline \multirow{2}{*}{ Aile Üyeleri } & Düşük & 265 & 3,17 & 1,33 & \multirow{2}{*}{$-3,80$} & \multirow{2}{*}{502,6} & \multirow{2}{*}{$<0,001$} \\
\hline & Yüksek & 327 & 3,55 & 1,07 & & & \\
\hline \multirow{2}{*}{ Arkadaş Çevresi } & Düşük & 265 & 3,03 & 1,17 & \multirow{2}{*}{$-1,63$} & \multirow{2}{*}{590} & \multirow{2}{*}{0,10} \\
\hline & Yüksek & 327 & 3,18 & 1,02 & & & \\
\hline \multirow{2}{*}{ Ünlü Kişiler } & Düşük & 265 & 1,86 & 0,96 & \multirow{2}{*}{$-3,89$} & \multirow{2}{*}{590} & \multirow{2}{*}{$<0,001$} \\
\hline & Yüksek & 327 & 2,17 & 0,97 & & & \\
\hline \multirow{2}{*}{ Siyasetçiler } & Düşük & 265 & 1,68 & 0,92 & \multirow{2}{*}{$-3,87$} & \multirow{2}{*}{590} & \multirow{2}{*}{$<0,001$} \\
\hline & Yüksek & 327 & 2,00 & 1,04 & & & \\
\hline \multirow{2}{*}{ Medya Mensupları } & Düşük & 265 & 2,18 & 1,07 & \multirow{2}{*}{$-3,16$} & \multirow{2}{*}{590} & \multirow{2}{*}{$0,002^{* *}$} \\
\hline & Yüksek & 327 & 2,46 & 1,06 & & & \\
\hline \multirow{2}{*}{$\begin{array}{l}\text { Sosyal Medya } \\
\text { Fenomenleri }\end{array}$} & Düşük & 265 & 1,56 & 0,85 & \multirow{2}{*}{$-2,69$} & \multirow{2}{*}{590} & \multirow{2}{*}{$0,007^{* \star}$} \\
\hline & Yüksek & 327 & 1,76 & 0,91 & & & \\
\hline \multirow{2}{*}{ Din Adamları } & Düşük & 265 & 1,56 & 0,97 & \multirow{2}{*}{$-2,90$} & \multirow{2}{*}{580,62} & \multirow{2}{*}{$0,004^{*}$} \\
\hline & Yüksek & 327 & 1,80 & 1,06 & & & \\
\hline \multirow{2}{*}{ Doktorlar } & Düşük & 265 & 4,49 & 0,73 & \multirow{2}{*}{1,03} & \multirow{2}{*}{590} & \multirow{2}{*}{0,30} \\
\hline & Yüksek & 327 & 4,43 & 0,66 & & & \\
\hline \multirow{2}{*}{$\begin{array}{l}\text { Doktorlar } \\
\text { Dışındaki Sağlık } \\
\text { Personeli }\end{array}$} & Düşük & 265 & 4,02 & 0,94 & \multirow{2}{*}{1,19} & \multirow{2}{*}{590} & \multirow{2}{*}{0,23} \\
\hline & Yüksek & 327 & 3,93 & 0,86 & & & \\
\hline
\end{tabular}

${ }^{* *} p<0,01$.

Tablo 10'da geleneksel medyayı kullanım sıklığı açısından COVID-19 bilgi kaynaklarından aile üyelerine $(t=-3,80 ; \mathrm{df}=502,6 ; p<0,001)$, ünlü kişiler $(t=-3,89 ; \mathrm{df}=590 ; p<0,001)$, siyasetçiler $(t=-3,87 ; \mathrm{df}=590 ; p<0,001)$, medya mensupları $(t=-3,16 ; \mathrm{df}=590 ; p<0,001)$, sosyal medya fenomenleri $(t=-2,69 ; \mathrm{df}=590 ; p<0,001)$ ve din adamlarına $(t=-2,90 ; \mathrm{df}=580,62 ; p<0,001)$ güven anlamlı bir biçimde farklık göstermektedir. Geleneksel medyayı yüksek sıklıkta kullanan katılımcılar, düşük sıklıkta kullanan katılımcılara kıyasla aile üyeleri, ünlü kişiler, siyasetçiler, medya mensupları, sosyal medya fenomenleri ve din adamlarına daha yüksek güven duymaktadır.

Sosyal medya kullanım sıklığı kümeleri açısından referans gruplarının güvenirliğinin anlamlı bir biçimde farklılaşıp farklılaşmadığını tespit edebilmek için bağımsız örneklemler t-test uygulanmıştır. Ulaşılan sonuçlar Tablo 11'de yer almaktadır.

Tablo 11. Sosyal Medya Kullanım Sıklığı Kümeleri Açısından Referans Gruplarının Güvenirliğinin İncelenmesi

\begin{tabular}{|c|c|c|c|c|c|c|c|}
\hline Referans Grubu & Küme & $\mathrm{n}$ & & SS & $\mathrm{t}$ & df & $\mathrm{p}$ \\
\hline \multirow{2}{*}{ Aile Üyeleri } & Düşük & 412 & 3,47 & 1,17 & \multirow{2}{*}{2,83} & \multirow{2}{*}{590} & \multirow{2}{*}{$0,005^{\star *}$} \\
\hline & Yüksek & 180 & 3,17 & 1,27 & & & \\
\hline \multirow{2}{*}{ Arkadaş Çevresi } & Düşük & 412 & 3,14 & 1,08 & \multirow{2}{*}{0,90} & \multirow{2}{*}{590} & \multirow{2}{*}{0,36} \\
\hline & Yüksek & 180 & 3,05 & 1,12 & & & \\
\hline
\end{tabular}




\begin{tabular}{|c|c|c|c|c|c|c|c|}
\hline \multirow{2}{*}{ Ünlü Kişiler } & Düşük & 412 & 2,07 & 0,99 & \multirow{2}{*}{1,26} & \multirow{2}{*}{590} & \multirow{2}{*}{0,20} \\
\hline & Yüksek & 180 & 1,96 & 0,94 & & & \\
\hline \multirow{2}{*}{ Siyasetçiler } & Düşük & 412 & 1,92 & 1,04 & \multirow{2}{*}{2,50} & \multirow{2}{*}{390,4} & \multirow{2}{*}{$0,013^{*}$} \\
\hline & Yüksek & 180 & 1,71 & 0,90 & & & \\
\hline \multirow{2}{*}{ Medya Mensupları } & Düşük & 412 & 2,36 & 1,08 & \multirow{2}{*}{1,13} & \multirow{2}{*}{590} & \multirow{2}{*}{0,25} \\
\hline & Yüksek & 180 & 2,26 & 1,05 & & & \\
\hline \multirow{2}{*}{ Sosyal Medya Fenomenleri } & Düşük & 412 & 1,68 & 0,89 & \multirow{2}{*}{0,37} & \multirow{2}{*}{590} & \multirow{2}{*}{0,70} \\
\hline & Yüksek & 180 & 1,65 & 0,88 & & & \\
\hline \multirow{2}{*}{ Din Adamları } & Düşük & 412 & 1,83 & 1,12 & \multirow{2}{*}{5,93} & \multirow{2}{*}{530,5} & \multirow{2}{*}{$<0,001$} \\
\hline & Yüksek & 180 & 1,38 & 0,68 & & & \\
\hline \multirow{2}{*}{ Doktorlar } & Düşük & 412 & 4,44 & 0,72 & \multirow{2}{*}{$-0,98$} & \multirow{2}{*}{590} & \multirow{2}{*}{0,32} \\
\hline & Yüksek & 180 & 4,50 & 0,62 & & & \\
\hline \multirow{2}{*}{$\begin{array}{l}\text { Doktorlar Dışındaki Sağlık } \\
\text { Personeli }\end{array}$} & Düşük & 412 & 3,96 & 0,92 & \multirow{2}{*}{$-0,40$} & \multirow{2}{*}{590} & \multirow{2}{*}{0,68} \\
\hline & Yüksek & 180 & 3,99 & 0,85 & & & \\
\hline
\end{tabular}

Tablo 11'de sosyal medyayı kullanım sıklığı açısından COVID-19 bilgi kaynaklarından aile üyelerine $(t=2,83 ; \mathrm{df}=590 ; p<0,01)$, siyasetçilere $(t=2,50 ; \mathrm{df}=390,4 ; p<0,01)$ ve din adamlarına $(t=5,93$; df $=530,5 ; p<0,01)$ yönelik güven anlamlı bir biçimde farklılaşmaktadır. Sonuçlar, sosyal medyayı yüksek sıklıkta kullanan katılımcıların düşük sıklıkta kullanan katılımcılara kıyasla aile üyelerine, siyasetçilere ve din adamlarına daha az güven duyduğunu gösterir niteliktedir.

\subsection{Medyaya yönelik güven açısından referans grupları güvenirliğinin incelenmesi}

Geleneksel medyaya yönelik güven kümeleri açısından COVID-19 bilgi kaynaklarına yönelik güvenin anlamlı biçimde farklııık gösterip göstermediğine yönelik olarak bağımsız örneklemler t-test uygulanmıştır. Sonuçlar Tablo 12'de yer almaktadır.

Tablo 12. Geleneksel Medyaya Yönelik Güven Kümeleri Açısından Referans Grupları Güvenirliğinin İncelenmesi

\begin{tabular}{|c|c|c|c|c|c|c|c|}
\hline Referans Grubu & Küme & $\mathrm{N}$ & & SS & $t$ & $d f$ & $p$ \\
\hline \multirow{2}{*}{ Aile Üyeleri } & Düşük & 412 & 3,27 & 1,24 & \multirow{2}{*}{$-4,09$} & \multirow{2}{*}{277,1} & \multirow{2}{*}{$<0,001$} \\
\hline & Yüksek & 180 & 3,71 & 1,05 & & & \\
\hline \multirow{2}{*}{ Arkadaş Çevresi } & Düşük & 412 & 3,00 & 1,10 & \multirow{2}{*}{$-4,56$} & \multirow{2}{*}{590} & \multirow{2}{*}{$<0,001$} \\
\hline & Yüksek & 180 & 3,47 & 0,98 & & & \\
\hline \multirow{2}{*}{ Ünlü Kişiler } & Düşük & 412 & 1,89 & 0,94 & \multirow{2}{*}{$-6,33$} & \multirow{2}{*}{590} & \multirow{2}{*}{$<0,001$} \\
\hline & Yüksek & 180 & 2,47 & 0,97 & & & \\
\hline \multirow{2}{*}{ Siyasetçiler } & Düşük & 412 & 1,67 & 0,91 & \multirow{2}{*}{$-7,73$} & \multirow{2}{*}{210,3} & \multirow{2}{*}{$<0,001$} \\
\hline & Yüksek & 180 & 2,44 & 1,07 & & & \\
\hline \multirow{2}{*}{ Medya Mensupları } & Düşük & 412 & 2,15 & 1,01 & \multirow{2}{*}{$-7,60$} & \multirow{2}{*}{231,7} & \multirow{2}{*}{$<0,001$} \\
\hline & Yüksek & 180 & 2,91 & 1,05 & & & \\
\hline \multirow{2}{*}{$\begin{array}{l}\text { Sosyal Medya } \\
\text { Fenomenleri }\end{array}$} & Düşük & 412 & 1,57 & 0,83 & \multirow{2}{*}{$-4,37$} & \multirow{2}{*}{211,7} & \multirow{2}{*}{$<0,001$} \\
\hline & Yüksek & 180 & 1,97 & 0,98 & & & \\
\hline \multirow{2}{*}{ Din Adamları } & Düşük & 412 & 1,58 & 0,95 & \multirow{2}{*}{$-4,44$} & \multirow{2}{*}{204,1} & \multirow{2}{*}{$<0,001$} \\
\hline & Yüksek & 180 & 2,06 & 1,17 & & & \\
\hline
\end{tabular}




\begin{tabular}{|c|c|c|c|c|c|c|c|}
\hline \multirow{2}{*}{ Doktorlar } & Düşük & 412 & 4,39 & 0,73 & \multirow{2}{*}{$-5,38$} & \multirow{2}{*}{350,7} & \multirow{2}{*}{$<0,001$} \\
\hline & Yüksek & 180 & 4,68 & 0,50 & & & \\
\hline \multirow{2}{*}{$\begin{array}{l}\text { Doktorlar } \\
\text { Dışındaki Sağlık } \\
\text { Personeli }\end{array}$} & Düşük & 412 & 3,89 & 0,93 & \multirow{2}{*}{$-4,04$} & \multirow{2}{*}{305,1} & \multirow{2}{*}{$<0,001$} \\
\hline & Yüksek & 180 & 4,20 & 0,72 & & & \\
\hline
\end{tabular}

Tablo 12'de geleneksel medyaya güven açısından COVID-19 bilgi kaynakları kapsamında ele alınan bütün gruplarda anlamlı bir farklılık tespit edilmiştir $(p<0,001)$. Bu bağlamda geleneksel medyaya yüksek düzeyde güven duyanlar düşük düzeyde güven duyanlarla kıyaslandığında sözü edilen bilgi kaynaklarına daha fazla güvenmektedir.

Sosyal medyaya güven kümeleri açısından referans gruplarının güvenirliğinin anlamlı bir biçimde farklılaşıp farklılaşmadığını tespit etmeye yönelik olarak bağımsız örneklemler t-test uygulanmıştır (Tablo 13).

Tablo 13. Sosyal Medyaya Yönelik Güven Kümeleri Açısından Referans Gruplarının Güvenirliğinin İncelenmesi

\begin{tabular}{|c|c|c|c|c|c|c|c|}
\hline Referans Grubu & Küme & $\mathrm{N}$ & & SS & $t$ & $d f$ & $p$ \\
\hline \multirow{2}{*}{ Aile Üyeleri } & Düşük & 287 & 3,12 & 1,34 & \multirow{2}{*}{$-5,14$} & \multirow{2}{*}{529,8} & \multirow{2}{*}{$<0,001$} \\
\hline & Yüksek & 305 & 3,62 & 1,01 & & & \\
\hline \multirow{2}{*}{ Arkadaş Çevresi } & Düşük & 287 & 2,74 & 1,16 & \multirow{2}{*}{$-8,46$} & \multirow{2}{*}{534,3} & \multirow{2}{*}{$<0,001$} \\
\hline & Yüksek & 305 & 3,46 & 0,89 & & & \\
\hline \multirow{2}{*}{ Ünlü Kişiler } & Düşük & 287 & 1,62 & 0,81 & \multirow{2}{*}{$-7,33$} & \multirow{2}{*}{582,2} & \multirow{2}{*}{$<0,001$} \\
\hline & Yüksek & 305 & 2,42 & 0,96 & & & \\
\hline \multirow{2}{*}{ Siyasetçiler } & Düşük & 287 & 1,56 & 0,87 & \multirow{2}{*}{$-7,33$} & \multirow{2}{*}{582,2} & \multirow{2}{*}{$<0,001$} \\
\hline & Yüksek & 305 & 2,14 & 1,04 & & & \\
\hline \multirow{2}{*}{ Medya Mensupları } & Düşük & 287 & 1,94 & 1,00 & \multirow{2}{*}{$-9,17$} & \multirow{2}{*}{587,8} & \multirow{2}{*}{$<0,001$} \\
\hline & Yüksek & 305 & 2,70 & 1,00 & & & \\
\hline \multirow{2}{*}{$\begin{array}{l}\text { Sosyal Medya } \\
\text { Fenomenleri }\end{array}$} & Düşük & 287 & 1,29 & 0,58 & \multirow{2}{*}{$-11,20$} & \multirow{2}{*}{498,8} & \multirow{2}{*}{$<0,001$} \\
\hline & Yüksek & 305 & 2,03 & 0,98 & & & \\
\hline \multirow{2}{*}{ Din Adamları } & Düşük & 287 & 1,47 & 0,92 & \multirow{2}{*}{$-5,33$} & \multirow{2}{*}{584,5} & \multirow{2}{*}{$<0,001$} \\
\hline & Yüksek & 305 & 1,90 & 1,08 & & & \\
\hline \multirow{2}{*}{ Doktorlar } & Düşük & 287 & 4,41 & 0,77 & \multirow{2}{*}{$-1,70$} & \multirow{2}{*}{543,9} & \multirow{2}{*}{0,090} \\
\hline & Yüksek & 305 & 4,50 & 0,61 & & & \\
\hline \multirow{2}{*}{$\begin{array}{l}\text { Doktorlar } \\
\text { Dışındaki Sağlık } \\
\text { Personeli }\end{array}$} & Düşük & 287 & 3,84 & 0,99 & \multirow[b]{2}{*}{$-3,42$} & \multirow[b]{2}{*}{542,5} & \multirow[b]{2}{*}{$0,001^{\text {** }}$} \\
\hline & Yüksek & 305 & 4,09 & 0,78 & & & \\
\hline
\end{tabular}

Tablo 13'te sosyal medyaya güven açısından COVID-19 bilgi kaynakları kapsamında doktorlar dışında ele alınan bütün gruplarda anlamlı bir farklıık tespit edilmiştir $(p<0,001)$. Bu bağlamda sosyal medyaya yüksek düzeyde güven duyanlar düşük düzeyde güven duyanlarla kıyaslandığında söz konusu bilgi kaynaklarına daha fazla güvenmektedir. Öte yandan doktorlar kapsamında bir farklılık çıkmaması sosyal medyaya düşük ya da yüksek düzeyde duyulan güven fark etmeksizin doktorlara güvenin yüksek olduğunu göstermektedir.

\subsection{Medya kullanım sıklığı açısından COVID-19 așısı olma kararında etkili olan referans grupların incelenmesi}

Geleneksel medya kullanım sıklığı açısından COVID-19 aşısı olma kararında etkili olan referans 
grupların anlamı bir biçimde farklılaşıp farklılaşmadığını ortaya çıkarmak amacıyla bağımsız örneklemler t-test uygulanmıştır (Tablo 14).

Tablo 14. Geleneksel Medya Kullanım Sıklığı Kümeleri Açııından Aşı Olma Kararında Etkili Olan Referans Grupların İncelenmesi

\begin{tabular}{|c|c|c|c|c|c|c|c|}
\hline Referans Grubu & Küme & $\mathrm{N}$ & & $S S$ & $t$ & $d f$ & $p$ \\
\hline \multirow{2}{*}{ Aile Üyeleri } & Düşük & 2,65 & 1,44 & 2,65 & \multirow{2}{*}{$-5,14$} & \multirow{2}{*}{547,1} & \multirow{2}{*}{$<0,001$} \\
\hline & Yüksek & 3,24 & 1,35 & 3,24 & & & \\
\hline \multirow{2}{*}{ Arkadaş Çevresi } & Düşük & 2,29 & 1,25 & 2,29 & \multirow{2}{*}{$-3,56$} & \multirow{2}{*}{590} & \multirow{2}{*}{$<0,001$} \\
\hline & Yüksek & 2,66 & 1,29 & 2,66 & & & \\
\hline \multirow{2}{*}{ Ünlü Kişiler } & Düşük & 1,40 & 0,73 & 1,40 & \multirow{2}{*}{$-3,78$} & \multirow{2}{*}{577,9} & \multirow{2}{*}{$<0,001$} \\
\hline & Yüksek & 1,68 & 1,05 & 1,68 & & & \\
\hline \multirow{2}{*}{ Siyasetçiler } & Düşük & 1,44 & 0,86 & 1,44 & \multirow{2}{*}{$-3,82$} & \multirow{2}{*}{589,5} & \multirow{2}{*}{$<0,001$} \\
\hline & Yüksek & 1,74 & 1,09 & 1,74 & & & \\
\hline \multirow{2}{*}{ Medya Mensupları } & Düşük & 1,54 & 0,86 & 1,54 & \multirow{2}{*}{$-4,18$} & \multirow{2}{*}{588,7} & \multirow{2}{*}{$<0,001$} \\
\hline & Yüksek & 1,88 & 1,11 & 1,88 & & & \\
\hline \multirow{2}{*}{$\begin{array}{l}\text { Sosyal Medya } \\
\text { Fenomenleri }\end{array}$} & Düşük & 1,33 & 0,67 & 1,33 & \multirow{2}{*}{$-1,75$} & \multirow{2}{*}{587,2} & \multirow{2}{*}{0,080} \\
\hline & Yüksek & 1,44 & 0,88 & 1,44 & & & \\
\hline \multirow{2}{*}{ Din Adamları } & Düşük & 1,33 & 0,78 & 1,33 & \multirow{2}{*}{$-3,46$} & \multirow{2}{*}{587,8} & \multirow{2}{*}{$0,001^{* x}$} \\
\hline & Yüksek & 1,59 & 1,02 & 1,59 & & & \\
\hline \multirow{2}{*}{ Doktorlar } & Düşük & 4,26 & 1,04 & 4,26 & \multirow{2}{*}{$-0,031$} & \multirow{2}{*}{590} & \multirow{2}{*}{0,976} \\
\hline & Yüksek & 4,26 & 1,03 & 4,26 & & & \\
\hline \multirow{2}{*}{$\begin{array}{l}\text { Doktorlar } \\
\text { Dışındaki Sağlık } \\
\text { Personeli }\end{array}$} & Düşük & 3,58 & 1,28 & 3,58 & \multirow[b]{2}{*}{$-0,25$} & \multirow[b]{2}{*}{590} & \multirow{2}{*}{0,80} \\
\hline & Yüksek & 3,61 & 1,30 & 3,61 & & & \\
\hline
\end{tabular}

Tablo 14'te geleneksel medya kullanım sıklığı açısından COVID-19 aşısı olma kararında etkili olan gruplardan aile üyeleri $(t=-5,14 ; \mathrm{df}=547,1 ; p<0,001)$, arkadaş çevresi $(t=-3,56 ; \mathrm{df}=590 ; p<0,001)$, ünlü kişiler ( $t=-3,78 ; \mathrm{df}=577,9 ; p<0,001)$, siyasetçiler $(t=-3,82 ; \mathrm{df}=589,5 ; p<0,001)$, medya mensupları $(t=-4,18 ; \mathrm{df}=588,7 ; p<0,001)$ ve din adamları $(t=-4,46$; df $=587,8 ; p<0,001)$ anlamlı bir biçimde farklılaşmaktadır. Nitekim geleneksel medyayı yüksek sıklıkta kullanan katılımcılar, düşük sıklıkta kullanan katılımcılara kıyasla aşı olma kararında söz konusu gruplardan daha çok etkilenmektedir.

Sosyal medya kullanım sıklığı açısından COVID-19 aşısı olma kararında etkili olan grupların anlamlı bir biçimde farklılaşıp farklılaşmadığını ortaya çıkarmaya yönelik bağımsız örneklemler t-test uygulanmıştır. Sonuçlar Tablo 15’tedir.

Tablo 15. Sosyal Medya Kullanım Sıklığı Kümeleri Açısından COVID-19 AşıSı Olma Kararında Etkili Olan Referans Grupların İncelenmesi

\begin{tabular}{|c|c|c|c|c|c|c|c|}
\hline Referans grupları & Küme & $\mathrm{n}$ & & $S S$ & $t$ & $d f$ & $p$ \\
\hline \multirow{2}{*}{ Aile Üyeleri } & Düşük & 412 & 3,08 & 1,42 & \multirow{2}{*}{2,59} & \multirow{2}{*}{590} & \multirow{2}{*}{$0,010^{*}$} \\
\hline & Yüksek & 180 & 2,75 & 1,40 & & & \\
\hline \multirow{2}{*}{ Arkadaş Çevresi } & Düşük & 412 & 2,58 & 1,29 & \multirow{2}{*}{2,64} & \multirow{2}{*}{590} & \multirow{2}{*}{$0,008^{* *}$} \\
\hline & Yüksek & 180 & 2,28 & 1,24 & & & \\
\hline \multirow{2}{*}{ Ünlü Kişiler } & Düşük & 412 & 1,62 & 0,99 & \multirow{2}{*}{2,89} & \multirow{2}{*}{428,1} & \multirow{2}{*}{$0,004^{* \star}$} \\
\hline & Yüksek & 180 & 1,41 & 0,78 & & & \\
\hline
\end{tabular}




\begin{tabular}{|l|c|c|c|c|c|c|c|} 
& Düşük & 412 & 1,67 & 1,04 & 2,40 & 396,7 & $0,017^{*}$ \\
Siyasetçiler & Yüksek & 180 & 1,47 & 0,89 & & & \\
& Düşük & 412 & 1,75 & 1,05 & 0,94 & 590 & 0,346 \\
Sosyal Medya & Yüksek & 180 & 1,67 & 0,94 & & & \\
Fenomenleri & Düşük & 412 & 1,43 & 0,82 & 1,86 & 376,7 & 0,063 \\
& Yüksek & 180 & 1,31 & 0,73 & & & \\
Din Adamları & Düşük & 412 & 1,58 & 1,01 & 4,89 & 516,1 & $<0,001$ \\
& Yüksek & 180 & 1,24 & 0,64 & & & \\
Doktorlar & Düşük & 412 & 4,25 & 1,01 & \multirow{2}{*}{0,59} & 590 & 0,55 \\
Doktorlar & Yüksek & 180 & 4,30 & 1,09 & & & \\
Dışındaki Sağlık & Düşük & 412 & 3,61 & 1,29 & & & \\
Personeli & Yüksek & 180 & 3,57 & 1,29 & 0,34 & 590 & 0,73 \\
\hline
\end{tabular}

Tablo 15'te sosyal medyayı kullanım sıklığı açısından COVID-19 aşısı olma kararında etkili olan gruplardan aile üyeleri $(t=2,59 ; \mathrm{df}=590 ; p<0,001)$, arkadaş çevresi $(t=2,64 ; \mathrm{df}=590 ; p<0,001)$, ünlü kişiler ( $t=2,89 ; \mathrm{df}=428,1 ; p<0,001)$, siyasetçiler $(t=2,49 ; \mathrm{df}=396,7 ; p<0,001)$, ve din adamları $(t=4,89 ; \mathrm{df}=516,1 ; p<0,001)$ anlamlı bir biçimde farklılaşmaktadır. Zira sosyal medyayı yüksek sıklıkta kullanan katılımcılar, düşük sıklıkta kullanan katılımcılara kıyasla söz konusu gruplardan aşı olma kararında daha çok etkilenmektedir.

\subsection{Medyaya yönelik güven açısından COVID-19 așıSı olma kararında etkili olan referans grupların incelenmesi}

Geleneksel medyaya güven açısından COVID-19 aşısı olma kararında etkili olan grupların anlamlı bir biçimde farklılaşıp farklılaşmadığının belirlenmesine yönelik olarak bağımsız örneklemler t-test uygulanmıştır. Ulaşılan sonuçlar Tablo 16'da verilmiştir.

Tablo 16. Geleneksel Medyaya Güven Kümeleri Açısından COVID-19 AşıSı Olma Kararında Etkili Olan Referans Grupların İncelenmesi

\begin{tabular}{|c|c|c|c|c|c|c|c|}
\hline Referans Grubu & Küme & $\mathrm{N}$ & & SS & $t$ & df & $p$ \\
\hline \multirow{2}{*}{ Aile Üyeleri } & Düşük & 449 & 2,84 & 1,42 & \multirow{2}{*}{$-4,33$} & \multirow{2}{*}{252,9} & \multirow{2}{*}{$<0,001$} \\
\hline & Yüksek & 143 & 3,41 & 1,33 & & & \\
\hline \multirow{2}{*}{ Arkadaş Çevresi } & Düşük & 449 & 2,35 & 1,25 & \multirow{2}{*}{$-4,92$} & \multirow{2}{*}{590} & \multirow{2}{*}{$<0,001$} \\
\hline & Yüksek & 143 & 2,94 & 1,29 & & & \\
\hline \multirow{2}{*}{ Ünlü Kişiler } & Düşük & 449 & 1,43 & 0,82 & \multirow{2}{*}{$-5,11$} & \multirow{2}{*}{193,1} & \multirow{2}{*}{$<0,001$} \\
\hline & Yüksek & 143 & 1,95 & 1,12 & & & \\
\hline \multirow{2}{*}{ Siyasetçiler } & Düşük & 449 & 1,49 & 0,91 & \multirow{2}{*}{$-4,68$} & \multirow{2}{*}{199,6} & \multirow{2}{*}{$<0,001$} \\
\hline & Yüksek & 143 & 1,99 & 1,17 & & & \\
\hline \multirow{2}{*}{ Medya Mensupları } & Düşük & 449 & 1,56 & 0,91 & \multirow{2}{*}{$-6,58$} & \multirow{2}{*}{202,3} & \multirow{2}{*}{$<0,001$} \\
\hline & Yüksek & 143 & 2,25 & 1,15 & & & \\
\hline \multirow{2}{*}{$\begin{array}{l}\text { Sosyal Medya } \\
\text { Fenomenleri }\end{array}$} & Düşük & 449 & 1,32 & 0,71 & \multirow{2}{*}{$-3,39$} & \multirow{2}{*}{190,8} & \multirow{2}{*}{$<0,001$} \\
\hline & Yüksek & 143 & 1,62 & 0,98 & & & \\
\hline \multirow{2}{*}{ Din Adamları } & Düşük & 449 & 1,37 & 0,81 & \multirow{2}{*}{$-4,19$} & \multirow{2}{*}{188,2} & \multirow{2}{*}{$<0,001$} \\
\hline & Yüksek & 143 & 1,80 & 1,16 & & & \\
\hline
\end{tabular}




\begin{tabular}{|l|c|c|c|c|c|c|c|} 
& Düşük & 449 & 4,15 & 1,11 & $-6,41$ & 431,8 & $<0,001$ \\
Doktorlar & Yüksek & 143 & 4,62 & 0,63 & & & \\
Dışındarlaki Sağlık & Düşük & 449 & 3,48 & 1,30 & & & \\
Personeli & Yüksek & 143 & 3,97 & 1,18 & $-4,22$ & 260,1 & $<0,001$ \\
\hline
\end{tabular}

Tablo 16'da geleneksel medyaya güven açısından COVID-19 aşısı olma kararında etkili olan bütün grupların anlamlı bir biçimde farklılaştığı görülmektedir $(p<0,001)$. Sonuç olarak, geleneksel medyaya yüksek düzeyde güven duyan katılımcıların aşı olma kararında etkili olan grupların tamamından daha fazla etkilenmektedir.

Sosyal medyaya güven açısından COVID-19 aşısı olma kararında etkili olan grupların anlamı bir biçimde farklılaşıp farklılaşmadığını belirlemeye yönelik bağımsız örneklemler t-test uygulanmıştır. Sonuçlar Tablo 17'de yer almaktadır.

Tablo 17. Sosyal Medyaya Güven Kümeleri Açısından COVID-19 Aşııı Olma Kararında Etkili Olan Referans Grupların Incelenmesi

\begin{tabular}{|c|c|c|c|c|c|c|c|}
\hline Referans Grubu & Küme & $\mathrm{N}$ & & $S S$ & $t$ & df & $p$ \\
\hline \multirow{2}{*}{ Aile Üyeleri } & Düşük & 287 & 2,65 & 1,44 & \multirow{2}{*}{$-5,61$} & \multirow{2}{*}{579,8} & \multirow{2}{*}{$<0,001$} \\
\hline & Yüksek & 305 & 3,29 & 1,34 & & & \\
\hline \multirow{2}{*}{ Arkadaş Çevresi } & Düşük & 287 & 2,14 & 1,18 & \multirow{2}{*}{$-6,77$} & \multirow{2}{*}{589,6} & \multirow{2}{*}{$<0,001$} \\
\hline & Yüksek & 305 & 2,83 & 1,29 & & & \\
\hline \multirow{2}{*}{ Ünlü Kişiler } & Düşük & 287 & 1,28 & 0,68 & \multirow{2}{*}{$-7,47$} & \multirow{2}{*}{523,2} & \multirow{2}{*}{$<0,001$} \\
\hline & Yüksek & 305 & 1,82 & 1,05 & & & \\
\hline \multirow{2}{*}{ Siyasetçiler } & Düşük & 287 & 1,38 & 0,87 & \multirow{2}{*}{$-5,42$} & \multirow{2}{*}{578,9} & \multirow{2}{*}{$<0,001$} \\
\hline & Yüksek & 305 & 1,82 & 1,07 & & & \\
\hline \multirow{2}{*}{ Medya Mensupları } & Düşük & 287 & 1,41 & 0,80 & \multirow{2}{*}{$-7,64$} & \multirow{2}{*}{553,7} & \multirow{2}{*}{$<0,001$} \\
\hline & Yüksek & 305 & 2,02 & 1,11 & & & \\
\hline \multirow{2}{*}{$\begin{array}{l}\text { Sosyal Medya } \\
\text { Fenomenleri }\end{array}$} & Düşük & 287 & 1,17 & 0,56 & \multirow{2}{*}{$-7,10$} & \multirow{2}{*}{505,6} & \multirow{2}{*}{$<0,001$} \\
\hline & Yüksek & 305 & 1,61 & 0,92 & & & \\
\hline \multirow{2}{*}{ Din Adamları } & Düşük & 287 & 1,31 & 0,78 & \multirow{2}{*}{$-4,34$} & \multirow{2}{*}{565,7} & \multirow{2}{*}{$<0,001$} \\
\hline & Yüksek & 305 & 1,63 & 1,02 & & & \\
\hline \multirow{2}{*}{ Doktorlar } & Düşük & 287 & 4,22 & 1,10 & \multirow{2}{*}{$-1,01$} & \multirow{2}{*}{569,7} & \multirow{2}{*}{0,29} \\
\hline & Yüksek & 305 & 4,30 & 0,97 & & & \\
\hline \multirow{2}{*}{$\begin{array}{l}\text { Doktorlar } \\
\text { Dışındaki Sağlık } \\
\text { Personeli }\end{array}$} & Düşük & 287 & 3,46 & 1,35 & \multirow[b]{2}{*}{$-2,63$} & \multirow[b]{2}{*}{575,1} & \multirow[b]{2}{*}{$0,009^{* *}$} \\
\hline & Yüksek & 305 & 3,73 & 1,22 & & & \\
\hline
\end{tabular}

${ }^{* *} p<0,01$.

Tablo 17'de sosyal medyaya güven açısından COVID-19 aşısı olma kararında etkili olan gruplardan doktorlar hariç $(p>0,05)$ bütün grupların anlamlı bir biçimde farklılaştığı görülmektedir $(p<0,001)$. Sosyal medyaya yüksek düzeyde güven duyan katılımcıların aşı olma kararında doktorlar dışında sıralanan referans gruplarının tamamından etkilendikleri görülmektedir. Ancak, referans grubu olarak doktorlar söz konusu olduğunda katılımcıların güven düzeyinin yüksek ya da düşük olması fark etmeksizin aşı olma kararında etkili bir referans grubu olduğu görülmektedir. 


\subsection{Medya kullanım sıklığı açısından COVID-19 algısı ve COVID-19 așısına yönelik tutumun incelenmesi}

Geleneksel ve sosyal medya kullanım sıklığı açısından COVID-19 algısının ve COVID-19 aşısına yönelik tutumun anlamlı bir biçimde farklılaşıp farklılaşmadığının ortaya konabilmesi için bağımsız örneklemler t-test istatistiği uygulanmıştır. Sonuçlar Tablo 18'de görülmektedir.

Tablo 18. Geleneksel ve Sosyal Medya Kullanım Sıklığı Açısından COVID-19 Algısı ve COVID-19 Aşısına Yönelik Tutumun İncelenmesi

\begin{tabular}{|c|c|c|c|c|c|c|c|c|c|}
\hline Kullanım sıklığı & Değişł & & Küme & $\mathrm{n}$ & & SS & $t$ & $d f$ & $p$ \\
\hline & COVID-19 & Tehlikelilik & $\begin{array}{l}\text { Düşük } \\
\text { Yüksek }\end{array}$ & $\begin{array}{l}265 \\
327\end{array}$ & $\begin{array}{l}2,02 \\
1,98\end{array}$ & $\begin{array}{l}1,02 \\
0,92\end{array}$ & 0,53 & 590 & 0,59 \\
\hline & Algısı & Bulasturiculuk & Düşük & 265 & 4,13 & 0,74 & 1 & 5668 & * \\
\hline Golenekcel Medva & & Dulaşmilctik & Yüksek & 327 & 3,98 & 0,75 & $2,7+4$ & 00,0 & 0,010 \\
\hline & & Olumlu & Düşük & 265 & 3,09 & 1,16 & 200 & 590 & 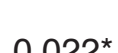 \\
\hline & COVID-19 & Tutum & Yüksek & 327 & 3,30 & 1,09 & $-2,29$ & 590 & 0,022 \\
\hline & Tutum & Olumsuz & Düşük & 265 & 2,66 & 0,82 & 107 & 590 & 028 \\
\hline & & Tutum & Yüksek & 327 & 2,59 & 0,80 & & & \\
\hline & & Tehlikelilik & Düşük & 412 & 2,05 & 0,93 & 161 & 590 & 011 \\
\hline & COVID-19 & 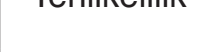 & Yüksek & 180 & 1,88 & 1,03 & (1, & 300 & , \\
\hline & Algısı & $k$ & Düşük & 412 & 3,98 & 0,77 & 0 & 500 & $\therefore *$ \\
\hline Srcual Modva & & BulaşıIICIIIK & Yüksek & 180 & 4,21 & 0,67 & $-3,39$ & 590 & 0,001 \\
\hline booyar ivicuya & & Olumlu & Düşük & 412 & 3,29 & 1,08 & 273 & 590 & $0007 * \star$ \\
\hline & COVID-19 & Tutum & Yüksek & 180 & 3,02 & 1,19 & 2,73 & 590 & $0,00 \%$; \\
\hline & $\begin{array}{l}\text { Tutum } \\
\text { The }\end{array}$ & Olumsuz & Düşük & 412 & 2,58 & 0,78 & 161 & 590 & 009 \\
\hline & & Tutum & Yüksek & 180 & 2,72 & 0,88 & $-1,04$ & 390 & 0,09 \\
\hline
\end{tabular}

${ }^{* *} p<0,01 ;{ }^{*} p<0,05$.

Geleneksel medya kullanım sıklığı açısından COVID-19 algısının bulaştırıcılık faktörü $(t=2,44 ; \mathrm{df}$ $=566,8 ; p<0,05)$ ile COVID-19 aşısına yönelik olumlu tutum $(t=-2,29 ; \mathrm{df}=590 ; p<0,05)$ arasında anlamlı bir fark görülmüştür. Bu bağlamda geleneksel medyayı yüksek sıklıkta kullanan katılımcılar, düşük sıklıkta kullananlarla kıyaslandığında COVID-19'un nispeten daha az bulaştırıcı olduğunu düşündüğü görülmektedir. Öte yandan, geleneksel medyayı yüksek sıklıkta kullananların düşük sıklıkta kullananlara göre COVID-19 aşısına yönelik daha olumlu tutuma sahip olduğu dikkat çekmektedir.

\subsection{Medyaya duyulan güven açısından COVID-19 algısının ve COVID-19 așısına yönelik tutumun incelenmesi}

Geleneksel ve sosyal medyaya güven açısından COVID-19 algısının ve COVID-19 aşısına yönelik tutumun anlamlı bir biçimde farklılaşıp farklılaşmadığının ortaya konabilmesi adına bağımsız örneklemler t-test uygulanmıştır. Ulaşılan sonuçlar Tablo 19'dadır. 
Tablo 19. Geleneksel ve Sosyal Medyaya Güven Açısından COVID-19 Algısının ve COVID-19 Aşısına Yönelik Tutumun İncelenmesi

\begin{tabular}{|c|c|c|c|c|c|c|c|c|c|}
\hline \multirow[t]{3}{*}{ Medyaya Güven } & \multicolumn{2}{|c|}{ Değişken } & Küme & $\mathrm{n}$ & & SS & $t$ & df & $p$ \\
\hline & \multirow{4}{*}{$\begin{array}{l}\text { COVID-19 } \\
\text { AlgISI }\end{array}$} & \multirow{2}{*}{ Tehlikelilik } & Düşük & 449 & 2,06 & 1,00 & \multirow{2}{*}{3,21} & \multirow{2}{*}{287,8} & \multirow{2}{*}{$0,001^{* *}$} \\
\hline & & & Yüksek & 143 & 1,79 & 0,82 & & & \\
\hline \multirow{2}{*}{$\begin{array}{l}\text { Geleneksel } \\
\text { Medyaya Yönelik }\end{array}$} & & \multirow{2}{*}{ Bulaştırıcılık } & Düşük & 449 & 4,01 & 0,77 & \multirow{2}{*}{$-2,52$} & \multirow{2}{*}{269,5} & \multirow{2}{*}{$0,012^{*}$} \\
\hline & & & Yüksek & 143 & 4,18 & 0,67 & & & \\
\hline \multirow{6}{*}{ Güven } & \multirow{4}{*}{$\begin{array}{c}\text { COVID-19 } \\
\text { Aşısına Yönelik } \\
\text { Tutum }\end{array}$} & Olumlu & Düşük & 449 & 3,07 & 1,15 & \multirow{2}{*}{$-5,29$} & \multirow{2}{*}{590} & \multirow{2}{*}{$<0,001$} \\
\hline & & Tutum & Yüksek & 143 & 3,63 & 0,93 & & & \\
\hline & & Olumsuz & Düşük & 449 & 2,68 & 0,81 & \multirow{2}{*}{2,94} & \multirow{2}{*}{590} & \multirow{2}{*}{$0,003^{* \star}$} \\
\hline & & Tutum & Yüksek & 143 & 2,45 & 0,79 & & & \\
\hline & & Teh & Düşük & 287 & 2,02 & 1,05 & 050 & 5603 & 031 \\
\hline & COVID-19 & 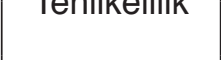 & Yüksek & 305 & 1,98 & 0,88 & 0,50 & 560,3 & 0,31 \\
\hline \multirow{6}{*}{$\begin{array}{l}\text { Sosyal } \\
\text { Medyaya Yönelik } \\
\text { Güven }\end{array}$} & Algısı & Bulastırıcılk & Düşük & 287 & 4,04 & 0,80 & \multirow{2}{*}{$-0,50$} & \multirow{2}{*}{590} & \multirow{2}{*}{0,60} \\
\hline & & & Yüksek & 305 & 4,07 & 0,70 & & & \\
\hline & \multirow{4}{*}{$\begin{array}{c}\text { COVID-19 } \\
\text { Aşısına Yönelik } \\
\text { Tutum }\end{array}$} & Olumlu & Düşük & 287 & 3,11 & 1,18 & \multirow{2}{*}{$-2,12$} & \multirow{2}{*}{590} & \multirow{2}{*}{$0,034^{*}$} \\
\hline & & Tutum & Yüksek & 305 & 3,30 & 1,06 & & & \\
\hline & & Olumsuz & Düşük & 287 & 2,63 & 0,86 & \multirow{2}{*}{0,31} & \multirow{2}{*}{590} & \multirow{2}{*}{0,75} \\
\hline & & Tutum & Yüksek & 305 & 2,61 & 0,76 & & & \\
\hline
\end{tabular}

Geleneksel medyaya güven açısından COVID-19 algısı ve COVID-19 aşısına yönelik tutum faktörlerinin anlamlı biçimde farklılaştı̆̆ı belirlenmiştir ( $p<0,001)$. COVID-19 algısı açısından geleneksel medyaya düşük düzeyde güven duyanlar COVID-19'un daha fazla tehlikeli olduğunu düşünürken, bulaştırıcılığının da nispeten daha az olduğunu değerlendirmektedir. COVID-19 aşısına yönelik tutum açısından geleneksel medyaya yüksek düzeyde güvenenler daha fazla olumlu tutuma sahip olurken, düşük düzeyde güvenenler daha fazla olumsuz tutuma sahiptir. Sosyal medyaya güven açısından COVID-19 algısı anlamlı bir biçimde farklılaşmazken, COVID-19 aşısına yönelik tutumda yalnızca olumlu tutum anlamlı bir biçimde farklılaşmaktadır. Bu sonuca göre sosyal medyaya yüksek düzeyde güven duyanlar COVID-19 aşısına yönelik daha olumlu tutuma sahip olmaktadır.

\section{Sonuç}

Bu çalışma, COVID-19 pandemisi ile ilgili bilgi edinmede referans gruplarına ve medyaya yönelik güveni (geleneksel ve sosyal medya), COVID-19 hastalığına yönelik algıyı ve COVID-19 aşısına yönelik tutumları ortaya çıkarma amacıyla gerçekleştirilmiştir. Bu bağlamda pandemi döneminde sıklıkla kullanılan mecralar incelendiğinde geleneksel medya bağlamında katıımcıların en sık kullandıkları mecra TV iken sosyal medya bağlamında Instagram olduğu görülmektedir. Medya kullanım alışkanlıkları bağlamında medya kullanım amaçları incelendiğinde katıımcılar medyayı; gündemi takip etmek, gelişmelerden haberdar olmak ve içerik (yorum, görsel, video) paylaşmak amacıyla kullanmaktadır.

Ülkemiz genelinde sosyal medya kullanım alışkanlıkları incelendiğinde, sosyal medya kullananların \%96'sının ayda bir kez sosyal medya platformları üzerinden mesajlaştı̆̆ı ve \%88'inin ise sosyal medya paylaşımlarıyla etkileşime geçtiği görülmektedir. Sosyal medyada harcanan süre ortalama 3 saat iken kullanıcı başına 9 sosyal medya hesabı bulunduğu görülmektedir (Bayrak, 2020). Dünya 
genelindeki veriler incelendiğinde insanların günlük yaklaşık 7 saati internet ortamında geçmektedir. İnsanların günde ortalama üç buçuk saat TV izlediği, sosyal medyada iki buçuk saat geçirdiği, kitap okumaya iki saat ayırdıkları, müzik dinlemek için bir buçuk saat harcadıkları, bir saat radyo / podcast dinledikleri ve de bir saat de oyun oynadıkları bir saat otuz dakika görülmektedir. Dünya genelinde internetin bilgi edinme amaçı kullanım oranı \%6 iken, en çok ziyaret edilen ilk üç site ise Google, Youtube ve Facebook'dur. Ayrıca 2020 yılında Google'da "Coronavirus" kelimesi en çok aranan on kelime arasından altıncı sırada yer almaktadır (Kemp, 2021). Bu sonuçlardan da anlaşılacağı üzere bilgiye erişime duyulan ihtiyaç ve ayrılan vakit arttıkça doğru bilgiye ulaşmanın önemi de aynı oranda artmaktadır.

Cobbey (1980) gazete okuyucuları ile yaptığı araştırmada medya kullanımı ve medya güvenirliği arasında doğrudan nedensel bir ilişkinin olduğunu ortaya koymuştur (aktaran Suher, 2017, s. 320). Bu çalışmada katılımcıların COVID-19 konusunda bilgi elde etmek için başvurdukları mecralar ve bu mecralara duydukları güven incelendiğinde; bilgi kaynağı olarak geleneksel medyayı tercih edenler TV'yi, sosyal medyayı tercih edenler ise İnternet haber ve sağlık sitelerini daha güvenilir bulmaktadır. Bu sonuçlar şaşırtıcı değildir. Çünkü gerek ana haber bültenleri gerekse pandemi ile ilgili yapılan programlarda konunun uzmanlarına yer verilmesi ve sağlık bakanlıklarının resmî açıklamalarının yer alması bakımından TV hala yoğun kullanılmaktadır. Aynı şekilde sosyal medya kullanıcılarının da ilk başvurduğu kaynak konu ile ilgili haber siteleridir. Bu durum sözü edilen mecranın bir haber kaynağı olarak kullanılan yapısından kaynaklanabilmektedir.

Sağlık Bakanlığı Sağlığın Geliştirilmesi Genel Müdürlüğü (SGGM) tarafından yürütülen "Türkiye Sağlık Okuryazarlığı Düzeyi ve İlişkili Faktörleri Araştırması” ile sağlık okuryazarlığı düzeyi ulusal düzeyde saptanmıştır. Çalışma sonucunda Türk toplumunun yarısının kitle iletişim araçlarında yer alan sağlıkla ilgili bilgilerin güvenirliğini değerlendirmede zorlandığı ortaya çıkmıştır. Bu sonuçtan hareketle sağlık alanında resmî kaynakların referans alınmasının ne kadar önemli olduğu görülmüştür (https://sggm.saglik.gov.tr/TR,57003/turkiyenin-saglik-okuryazarligi-duzeyi-olculdu.html).

Katılımcıların COVID-19 ile ilgili konularda bilgi almak için hangi referans grubunun ne derecede güvenilir bulunduğuna yönelik bulgular incelendiğinde, en güvenilir bulunan kaynak doktorlar iken en düşük güven sosyal medya fenomenlerine duyulmaktadır. Çalışmada, aşı olma kararına etki eden kişi/gruplar incelendiğinde katılımcıların aşı olma kararlarını en çok etkileyen grubun doktorlar, en az etkileyen grubun ise sosyal medya fenomenleri olduğu görülmektedir. Geleneksel medyayı yüksek sıklıkta kullanan katılımcılar, düşük sıklıkta kullanan katılımcılara kıyasla aile üyeleri, ünlü kişiler, siyasetçiler, medya mensupları, sosyal medya fenomenleri ve din adamlarına daha yüksek güven duymaktadır. Sosyal medyaya düşük ya da yüksek düzeyde duyulan güven fark etmeksizin doktorlara güvenin yüksek olduğunu göstermektedir. Bulgularda doktorlar ve diğer sağlık çalışanlarına yönelik güven duygusunun yüksek olması doğru bilgiye doğru kaynaktan ulaşmanın bireyler tarafından öneminin kavrandığını göstermektedir. COVID-19 gibi insan hayatını en ciddi şekilde tehdit eden bir pandemi ortamında bu sonuç toplumsal sağlığı koruma adına ayrı bir önem taşımaktadır.

COVID-19 ve aşıya yönelik ölçeklerden elde edilen sonuçlar incelendiğinde, COVID-19 algısı açısından geleneksel medyaya düşük düzeyde güven duyanlar COVID-19'un daha fazla tehlikeli olduğunu düşünürken, bulaştırıcılığının da nispeten daha az olduğunu değerlendirmektedir. Burada sosyal medyada serbestçe dolaşımda bulunan yüzbinlerce içeriğin (görseller, videolar, yorumlar vb) etkisi olduğu düşünülmektedir. COVID-19 aşısına yönelik tutum açısından geleneksel medyaya 
yüksek düzeyde güvenenler daha fazla olumlu tutuma sahip olurken, düşük düzeyde güvenenler daha fazla olumsuz tutuma sahiptir. Televizyonlarda her gün konu ile ilgili bilgi veren sağlık otoriteleri insanları ikna etmede önemli rol oynamaktadır. Sağlık Bakanlığı'nın tüm ulusal televizyon ve radyo kanallarında canlı verilen basın toplantılarında ya da ana haber bültenleri ve haber programlarında yer alan sağlık otoritelerinin COVID-19 ile mücadelede aşılanmanın önemine dair açıklamaları güven duygusunu pekiştirirken sosyal medyayı yoğun kullananlar burada maruz kaldıkları kontrolsüz ve güvenilirliği tartışmalı aşı karşıtı yayınlar ve komplo teorilerinden olumsuz yönde etkilenebilmektedir.

Toplum sağlığına yönelik olarak geliştirilen stratejilerinin uygulamaya konmasında tek başına yasal düzenlemeler yeterli olmamakta ve uygulanabilirliğinin kamuoyunun kabulüyle de desteklenmesi de gerekmektedir. Toplumsal kabulün gerçekleşmesi için gerekenlerden biri de kuşkusuz sağlık iletişimidir. Sağlık iletişimi, halk sağlığına yönelik önlemlere uyumu kolaylaştırmasının yanı sıra, sorunlara müdahale biçiminin de başarılı bir biçimde idare edilmesine destek sağlayabilecek bir takım toplumsal tedbirlerin alınması açısından da elzemdir (Gölbaşı ve Metintaş, 2020, s.131).

Bu çalışma pandemi şartlarının sınırlılıklarında gerçekleştirilmiştir. Daha derinlemesine veriler elde edebilmek ve toplumun tüm kesimlerinin görüşlerini kapsayabilmek adına daha detaylı çalışmalara ihtiyaç vardır. Referans gruplarının neden güvenilir bulunduğu, kaynak güvenirliğinin hangi boyutları ile öne çıktığı, bireylerin sağlık okuryazarlık düzeyleri ve bilgi edinme kaynakları arasındaki ilişki boyutu ileriki çalışmaların konusu olabileceği düşünülmektedir.

\section{Kaynakça}

Aker, A. A. (2018). Aşı Karşıtlığı. Toplum ve Hekim, 33(3), 175-186.

Arifin, W. N. (2015). The graphical assessment of multivariate normality using SPSS. Education in Medicine Journal, 7(2), 71-75.

Ataç, Ö. ve Aker, A. (2014). Aşı Karşıtlığı. SD Sağlık Düşüncesi ve Tıp Kültürü Dergisi. İlkbahar, $42-47$.

Aydın, A. F. (2020). Post-Truth Dönemde Sosyal Medyada Dezenformasyon: Covid-19 (Yeni Koronavirüs) Pandemi Süreci. Asya Studies- Academic Social Studies/Akademik Sosyal Araştırmalar, 4 (12), 76-90.

Bertin, P., Nera, K. ve Delouvee, S. (2020). Conspiracy Beliefs, Rejection of Vaccination, and Support for hydroxychloroquine: A Conceptual Replication-Extension in the COVID-19 Pandemic Context. Frontiers in Psychology, 11, 1-9.

Bolatkale, M.K., Kutlu, R. ve Eryılmaz, M.A. (2019). Aile Hekimliği Polikliniğine Başvuran Bireylerin Erişkin Aşıları Hakkındaki Bilgileri ve Aşılanma Durumları. Konuralp Tıp Dergisi, 11(3), 362-368.

Bozkurt, H. B. (2018). Aşı Reddine Genel Bir Bakış ve Literatürün Gözden Geçirilmesi. Kafkas Journal of Medical Sciences, 8(1), 71-76.

Creswell, J. W. (2014). Educational research: Planning, conducting, and evaluating quantitative and qualitative research. New York: Pearson.

Geniş, B., Gürhan, N., Koç, M., Geniş, Ç., Şirin, B., Çırakoğlu, O.C. ve Coşar, B. (2020). Development of Perception and Attitude Scales Related With Covid-19 Pandemia. Pearson Journal of Social Sciences \& Humanities, 5(7), 306-326.

Gölbaşı, S. D. ve Metintaş, S. (2020). Covıd-19 Pandemisi ve İnfodemi. Halk Sağlığı Dergisi, 5(COVID-19 Özel SayıSı), 126-37.

Hair, J. F., Black, W. C., Babin, B. J., and Anderson, R. E. (2014). Multivariate data analysis. New York: Pearson. 
Karaca, Y. (2016). Referans Grupları ile İletişimin satın Alma Kararları Üzerine Etkisi: Genç Yetişkinlere Yönelik Bir Araştırma. Galatasaray Üniversitesi Illetişim Dergisi, 25, 209-231.

Kılıçaslan, Ö. (2020). Aşı Karşıtığı Tarihçesi. Cengiz Yakıncı (Ed.), Güncel Çocuk Sağı̆̆ı ve Hastalıkları içinde (s. 2542), Ankara: Akademisyen Kitabevi.

Kırık, A. M. ve Özkoçak, V. (2020). Yeni Dünya Düzeni Bağlamında Sosyal Medya Ve Yeni Koronavirüs (Covıd-19) Pandemisi. SOBIDER Sosyal Bilimler Dergisi, 7(45), 133-154.

Okyay, P. ve Abacıgil, F. (2016). Türkiye Sağlık Okuryazarlığı Ölçekleri Güvenilirlik ve Geçerlilik Çalışması. Ankara: Sağıık Bakanlığı Yayın No: 1025.

Özata, F. Z. ve Kapusuz, S. (2019). Aşı Kararsızıı̆ı ve Aşı Reddi Konusuna Sosyal Pazarlama Bakış Açısından Çözüm Önerileri. Anadolu Üniversitesi İktisadi ve İdari Bilimler Fakültesi Dergisi, 20(1), 65-83.

Özdemir, S., Kayhan, R ve Aksoy Özer İ. (2021). Pandemi (Covid-19) Döneminde Kaynak Güvenilirliği Boyutlarının, Elektronik Ağızdan Ağıza İletişimin ve Marka İmajı Boyutlarının Tüketici Satın Alma Niyeti Üzerindeki Etkisi: Instagram Fenomenleri Üzerine Bir Araştırma. Pazarlama ve Pazarlama Araştırmaları Dergisi, 14(1), 113-146.

Pallant, J. (2011). SPSS survival manual: A step-by-step guide to data analysis using SPSS. New York: Open University Press.

Suher, K. İ. (2017). Kaynak Güvenilirliği. Edt. A. A. Bir ve H. K. Suher, (Ed), Reklam Teorileri: Reklamın Insan Davranışına Etkileri içinde (295-332). İstanbul: The Kitap Yayınları.

Türkay, M., Ay, E.G. ve Aktekin, M.R. (2017). Antalya İlinde Seçilmiş Bir Grupta Aşı Karşıtı Olma Durumu. Akdeniz Tıp Dergisi, 2, 107-112.

Covid-19 Pandemi Değerlendirme Raporu. (2020). TÜBA Raporları No: 34. Ankara: Türkiye Bilimler Akademisi Yayınları.

Uyar, M., Yıldırım, E.N. ve Şahin, T.K. (2019). On Sekiz Yaş ve Üzeri Erişkin Bireylerin Aşılar ve Aşılama Hakkındaki Bilgi, Tutum ve Davranışlarının Belirlenmesi. FLORA İnfeksiyon Hastalıkları ve Klinik Mikrobiyoloji Dergisi, 24(4), 288294.

Yılmaz, R. A. ve Şahin, Ö. D. (2019) Post-Truth Dönemde İtibarı Korumak: Sosyal Medyada Marka Krizleri Üzerine Bir İnceleme. e-Kurgu, Prof. Dr. Alâeddin Asna Anısına Yeni Zamanlar ve Halkla Illişkiler Sempozyumu Özel Sayısı, 27(4), 137-157.

Yüksel, H. G. ve Topuzoğlu, A. (2019). Aşı Redlerinin Artması ve Aşı Karşıtığını Etkileyen Faktörler. ESTÜDAM Halk Sağlığı Dergisi, 4(2), 244-58.

İnternet Kaynakları

Hunt, J.S. (2020). The COVID-19 Pandemic vs Post-Truth (executive summary). Global Health Security Network. https://www.ghsn.org/resources/Documents/GHSN\%20Policy\%20Report\%201.pdf adresinden 29.12.2020 tarihinde erişilmiştir.

Kemp, S. (2021). The Digital 2021 Global Overview Report.

https://wearesocial.com/uk/blog/2021/01/digital-2021-the-latest-insights-into-the-state-of-digital adresinden 15.01.2021 tarihinde erişilmiştir.

Türkiye'nin Sağlık Okuryazarlığı Düzeyi Ölçüldü.

https://sggm.saglik.gov.tr/TR-57003/turkiyenin-saglik-okuryazarligi-duzeyi-olculdu.html adresinden 03.01.2021 tarihinde erişilmiştir. 
Bayrak, H. (2020). 2020 Türkiye İnternet Kullanımı ve Sosyal Medya İstatistikleri.

https://dijilopedi.com/2020-turkiye-internet-kullanimi-ve-sosyal-medya-istatistikleri/adresinden

11.12 .2020

tarihinde erişilmiştir.

\section{Extended Abstract}

\section{Purpose of Research}

The aim of this study is to reveal the trust in reference groups and the media, the perception of COVID-19 disease and attitudes towards the COVID-19 vaccine in obtaining information about the COVID-19 pandemic. During the COVID-19 pandemic, users' media usage frequencies and their trust in media platforms (traditional and social media) were tried to be clustered to determine the media usage frequency of the participants and their level of trust in media platforms. Also, it has been tried to understand how the trust in reference groups in obtaining information about the COVID-19 pandemic, the perception of COVID-19 disease and attitudes towards the COVID-19 vaccine have changed in terms of media usage frequency and levels of trust in media platforms.

\section{Research Questions}

This research analyzes the individuals' information sources, media usage habits and attitudes towards vaccination in the COVID-19 pandemic with some questions such as "how are participants clustered in terms of trust in media platforms?", "in terms of the level of trust in media platforms, do the reference groups that are influential in the decision to get the COVID-19 vaccine differ significantly?", "does the perception of COVID-19 disease differ significantly in terms of media use frequency?"

\section{Literature Review}

Contrary to traditional media such as television and newspapers, people in the internet environment have turned from passive buyers to active information seekers who want to access information instantly. There has been an increase in the use of social media in this transformation process. (Yılmaz ve Şahin, 2019, s.139). In this study, the reliability of various reference groups, such as family members, doctors, politicians and media, in obtaining information about COVID-19 and getting the COVID-19 vaccine was examined. The reliability of mass media is defined as being honest with the public. Reliability studies are divided into sub-areas, such as the reliability of the newspaper against television, according to the characteristics of the medium. There are many studies where TV is seen as the most reliable source (aktaran Suher, 2017, s.320). In this study, the reliability of traditional media against social media is also discussed.

\section{Methodology}

In this study, a cross-sectional survey model was used. The data were obtained by the online questionnaire and 600 people aged 18 and over were reached with the snowball sampling method. Questionnaire consist of 5 parts: Demographic information; Media usage habits, frequencies and trust in media platforms; Reliance on COVID-19 information resources; Perceptions of COVID-19 and Attitudes towards the COVID-19 vaccine. 


\section{Results and Conclusion}

When the media that are frequently used during the pandemic period are examined, it is seen that the most frequently used media by the participants in the context of traditional media is TV, while Youtube is the context of social media. When the media usage purposes are examined in the context of media usage habits, participants use the media to follow the agenda, keep up to date with developments and share content (comments, images, videos), respectively. When the channels used by the participants to obtain information about COVID-19 and their trust in these channels are examined; Those who prefer traditional media as a source of information find TV more reliable, and those who prefer social media find internet news and health sites more reliable. When the findings of which reference group is found to be reliable to get information on COVID-19-related issues, the most reliable source is doctors, while the lowest trust is felt to social media influencers. In the study, when the people/groups affecting the decision to be vaccinated are examined, it is seen that the group that most influences the decision of the participants to be vaccinated is the doctors, and the group that affects the least is the clergy. Participants who use traditional media with a high frequency have higher trust in family members, famous people, politicians, members of the media, social media influencers and clergy compared to those who use it less frequently. In terms of attitude towards the COVID-19 vaccine, those with high reliance on traditional media have more positive attitudes, while those with low trust have more negative attitudes.

The accuracy of the information spread in the field of health is very important. From which source the information was obtained and the reliability of these sources is an issue that should be emphasized. Especially in the new media, disguised as different identities, a lot of information, which is not subject to control and whose accuracy is controversial, is distributed in the communication universe. One of these issues that vitally concern our health is the COVID-19 pandemic and vaccine studies for it. In this study, individuals' sources of information about the COVID-19 pandemic, their perceptions of trust in the media, and their attitudes towards vaccination were examined in a process where information pollution is intense. 